\title{
Priročnik \\ za tehnično oblikovanje zaključnih del \\ v programu Microsoft Word
}

Nina Krmac

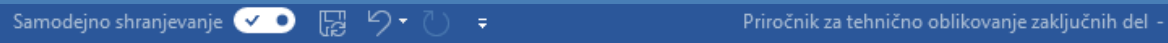

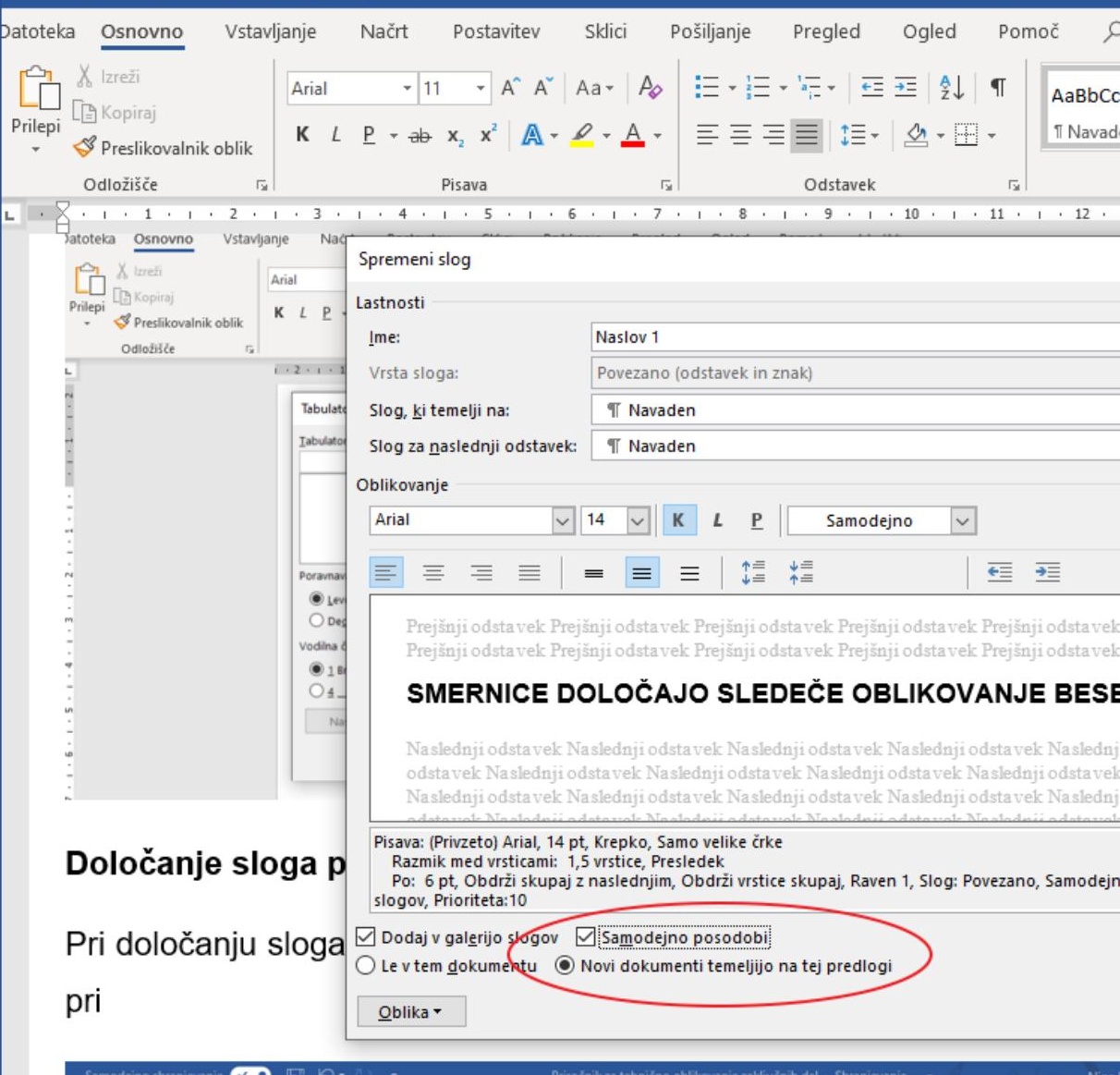

\section{Stolpec}

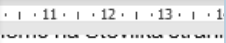
evilka 2. Od sedaj dalj stolpcit, da se bo besedilo, ki sledi prelom

oblivanje $\mathrm{z}$ besedilom

Ločite besedilo okoli predmetov na spletnih straneh, na primer besedilo napisa od besedila telesa.

Prelomi odseka

Naslednja stran

Vstavi prelom odseka in začni nov odsek na naslednji strani.

Neprekinjeno

Vstavi prelom odseka in začni nov odsek na isti strani.

Soda stran

Vstavi prelom odseka in začni nov odsek na naslednji sodi strani.

Lịha stran 


\section{KAZALO VSEBINE}

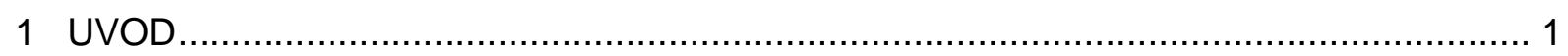

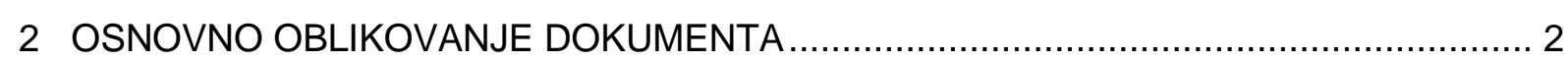

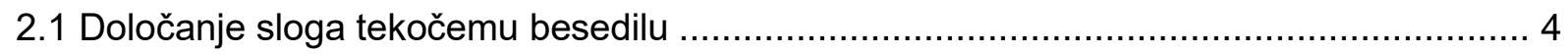

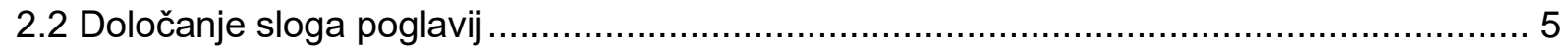

2.3 Določanje sloga naslovom ponazoril .................................................................. 7

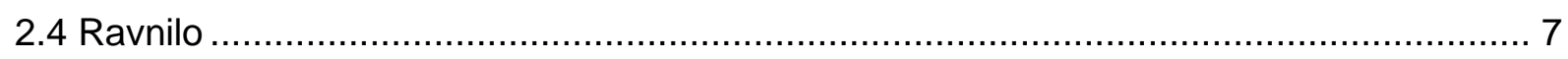

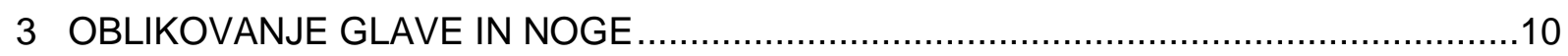

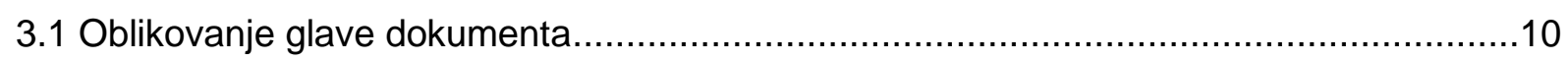

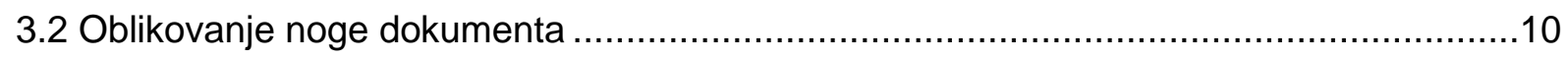

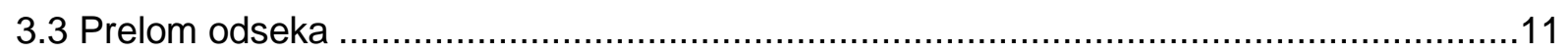

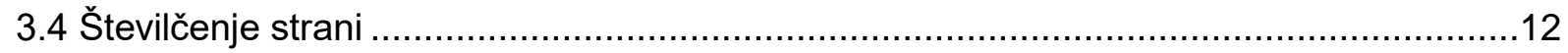

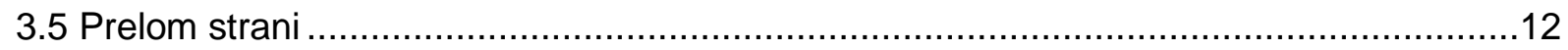

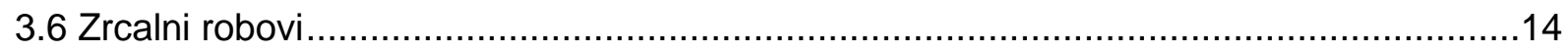

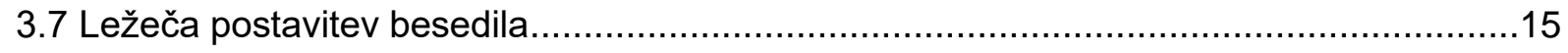

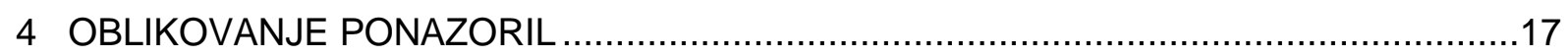

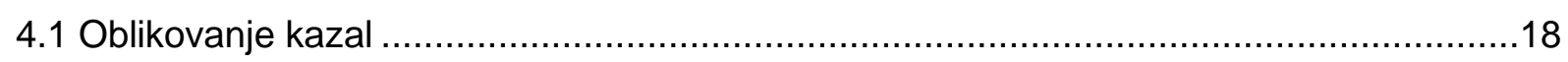

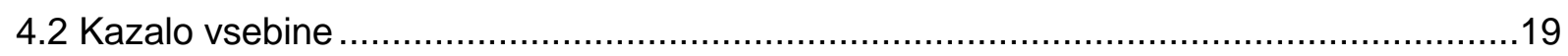

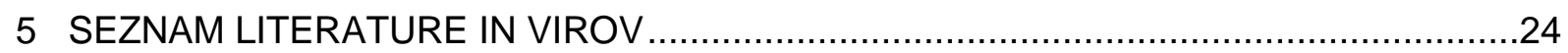

6 UPORABNO .

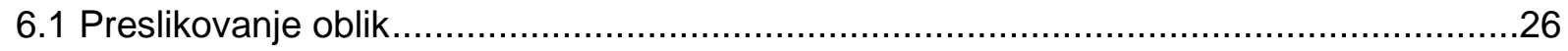

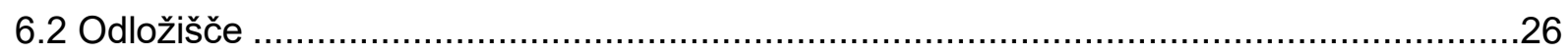

6.3 Vnos pripombe

6.4 Sprotna opomba

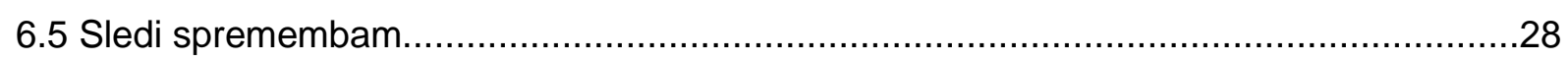

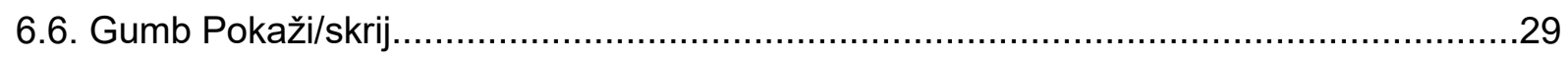

6.7 Odstranjevanje skritih podatkov in osebnih informacij...............................................30

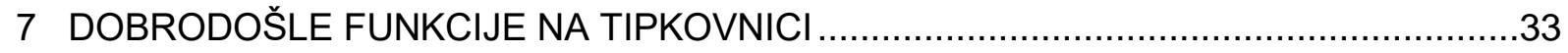

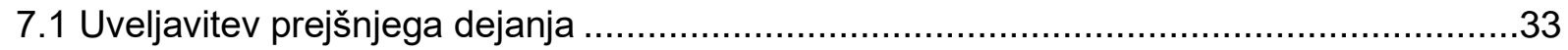

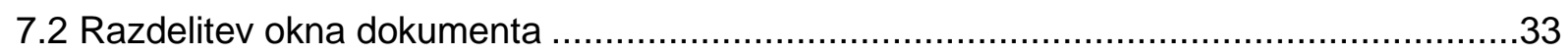

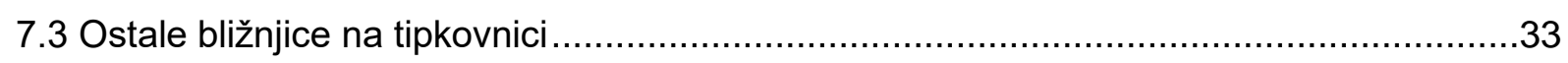

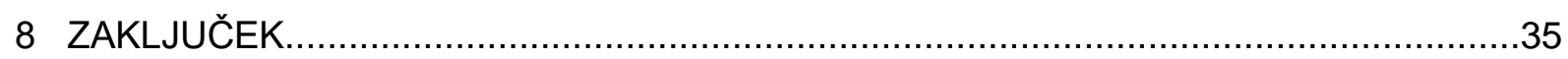

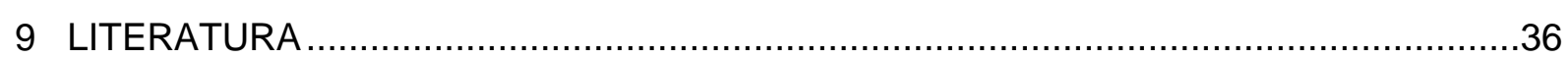




\section{KAZALO SLIK}

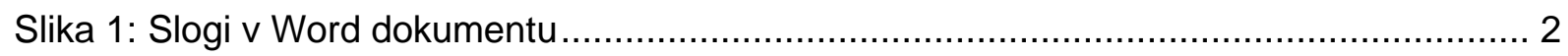

Slika 2: Sprememba nastavitev slogov .................................................................... 2

Slika 3: Osnovno oblikovanje tekočega besedila in poglavij .......................................... 3

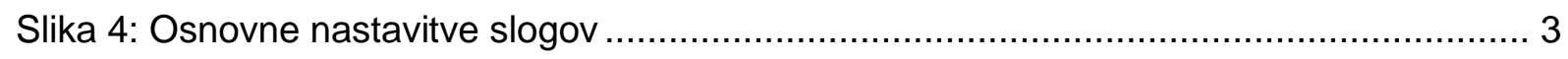

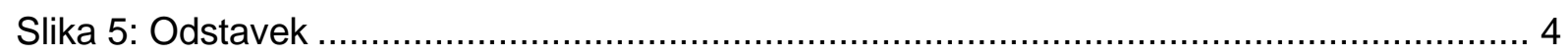

Slika 6: Določanje sloga tekočemu besedilu ............................................................ 4

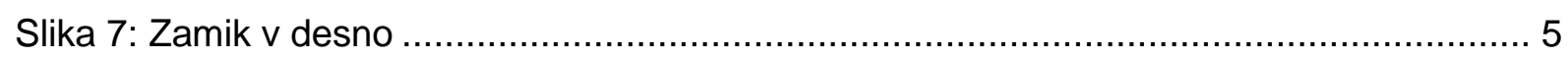

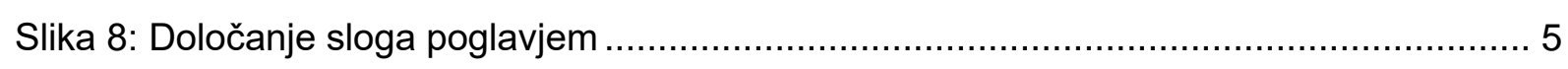

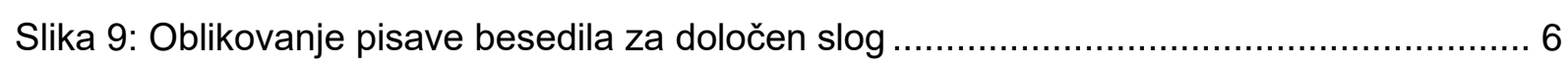

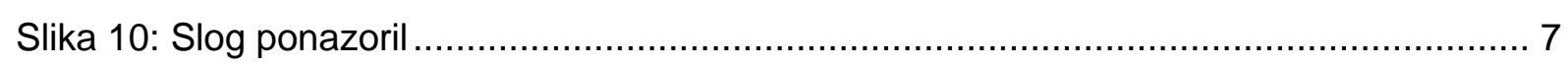

Slika 11: Platnica in prva notranja stran zaključnega dela (povzeto po Smernice za izdelavo

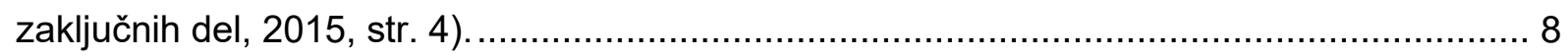

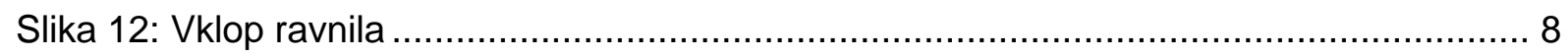

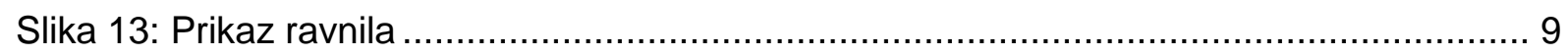

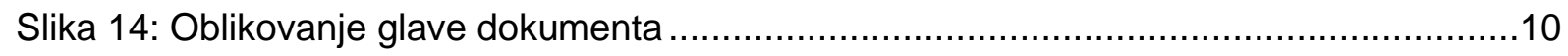

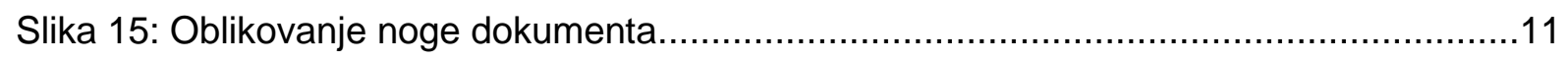

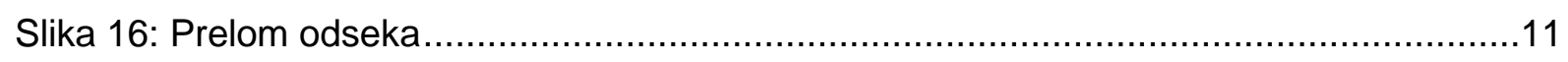

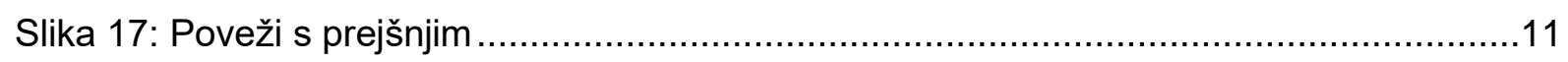

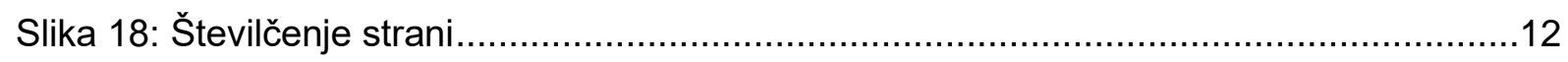

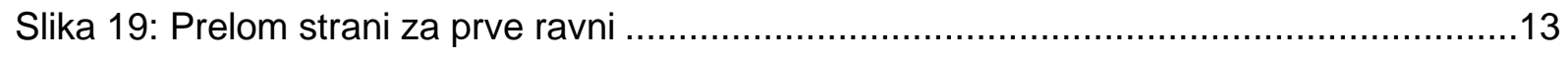

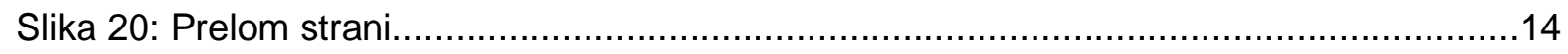

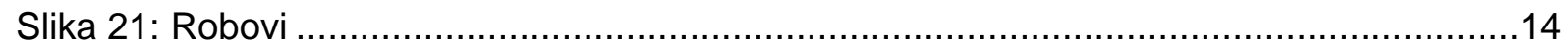

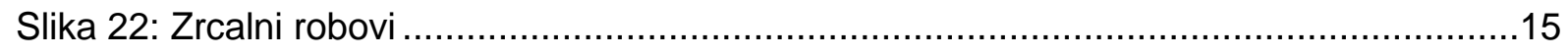

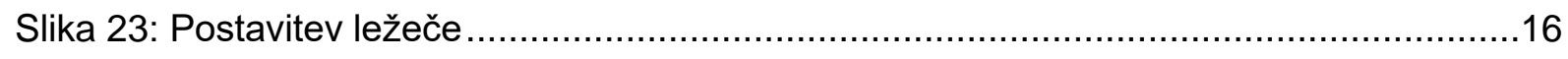

Slika 24: Ležeča postavitev besedila ....................................................................16

Slika 25: Oblikovanje samodejnega ponazorila .......................................................... 17

Slika 26: Sprememba naslova ponazorila..............................................................17

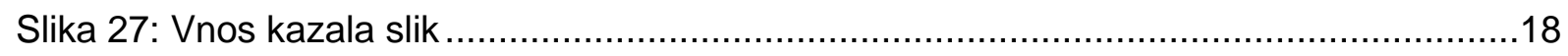

Slika 28: Nastavitev izbire oblikovanja kazala ponazoril .............................................19

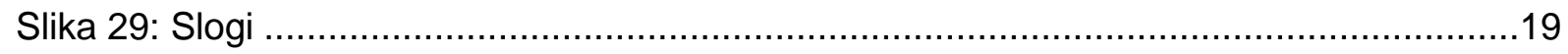

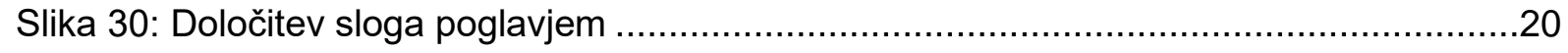

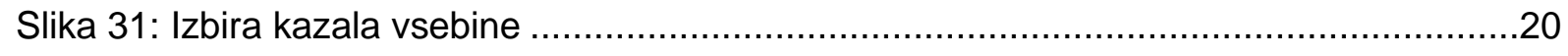

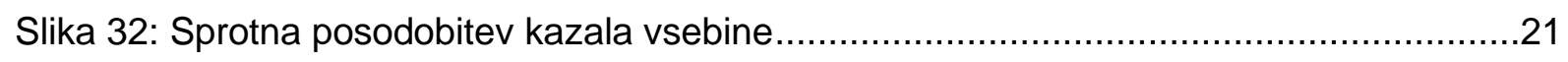

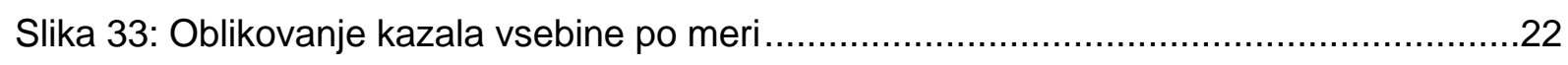

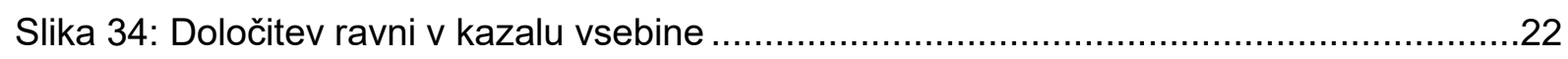


Slika 35: Razvrstitev virov in literature po abecednem vrstnem redu .24

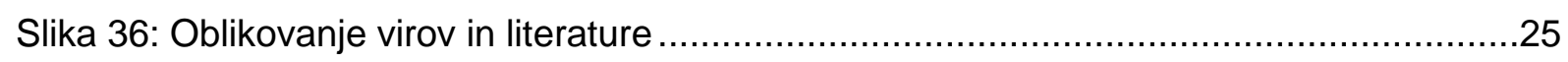

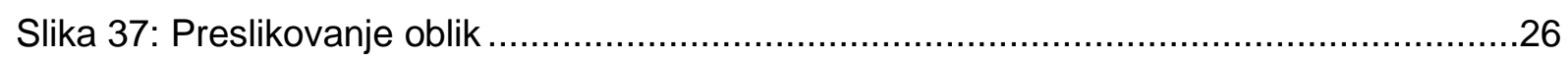

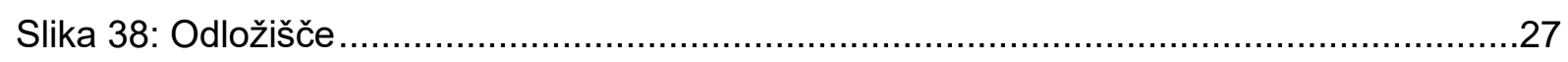

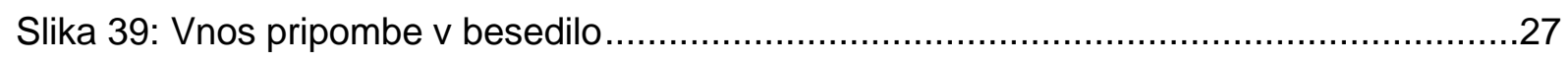

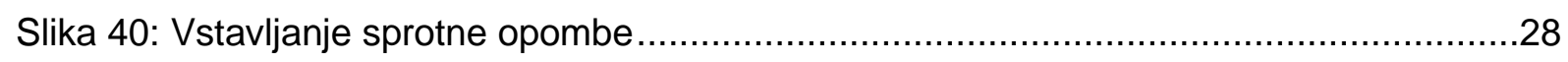

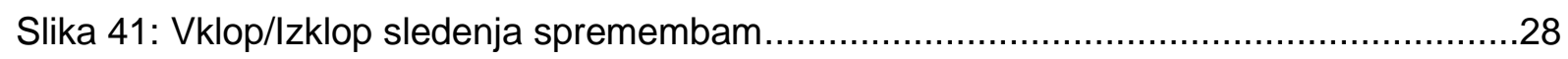

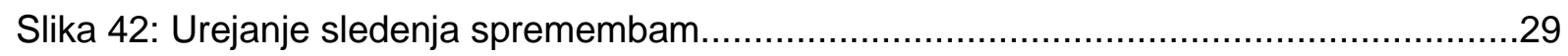

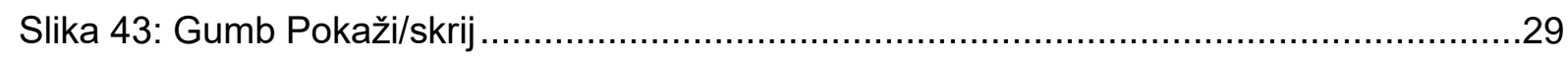

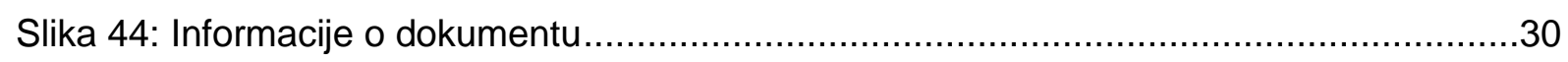

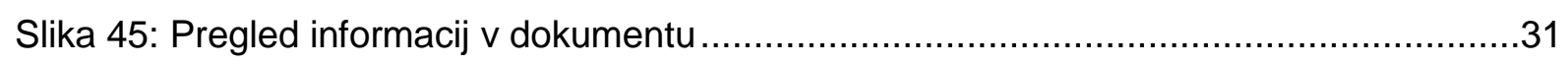

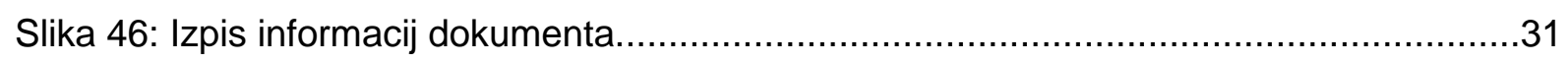

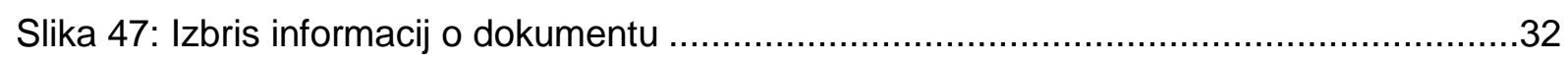

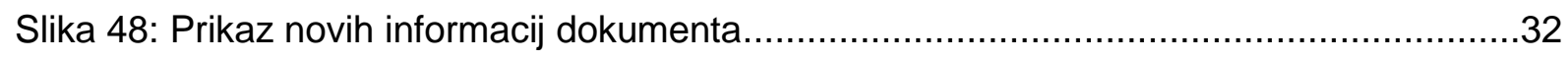

\section{KAZALO PREGLEDNIC}

Preglednica 1: Bližnjice na tipkovnici (povzeto po Bližnjice na tipkovnici v Wordu, 2020) .....33 



\section{UVOD}

Priročnik je namenjen vsem tistim, ki potrebujejo pomoč pri tehničnem oblikovanju seminarskih in zaključnih del ali pa poljubnega dokumenta $v$ programu Microsoft Word. Posebej je namenjen študentom pri pisanju seminarskih in zaključnih del. Za nazoren prikaz funkcij v Word dokumentu smo dokument uredili na podlagi Smernic za izdelavo zaključnih del (2015), ki jih določa Pedagoška Fakulteta Univerze na Primorskem (v nadaljevanju smernice UP PEF).

Tako je priročnik še dodatno koristen za študente Pedagoške fakultete Univerze na Primorskem, ker vsebuje določila smernic UP PEF. Priročnik sicer prikazuje glavne funkcije in ukaze, ki so potrebni za urejanje vsakršnega dokumenta.

Ukazi so prikazani v Word dokumentu s pomočjo slikovnega prikaza. Prikaz oblikovanja je bil opravljen v slovenski različici Microsoft Word za Microsoft 365 (16.0.11929.20436), vendar bo ustrezen tudi za različice Word 2019, Word 2016 in Word 2013. Na podlagi opravljenih delavnic za tehnično oblikovanje seminarskih in zaključnih del so $v$ priročniku posebej izpostavljene rešitve problemov, s katerimi so se študentje UP PEF najpogosteje soočali pri tehničnem oblikovanju.

Priročnik vključuje prikaz različnih ukazov, kot so številčenje strani, prelomi odsekov, zrcalni robovi itd. $\mathrm{V}$ zaključnem delu priročnika so uporabnikom priročnika prikazane še številne bližnjice na tipkovnici, ki pri oblikovanju dokumentov prihranijo veliko časa.

Uporabo priročnika se predlaga že pred pričetkom pisanja dokumenta, saj določene funkcije bistveno olajšajo proces pisanja in oblikovanja, če jih predhodno nastavimo. 


\section{OSNOVNO OBLIKOVANJE DOKUMENTA}

Pri oblikovanju vsakega dokumenta je pomembno, da si najprej nastavimo slog pisave (tip pisave, velikost črk itd.) posebej za besedilo in poglavja, kot je določeno v smernicah.

Po smernicah UP PEF je:

- celotno besedilo zapisano v navadni pisavi (pokončni znaki) Arial;

- glava, jedrno (tekoče) besedilo in noga so obojestransko poravnani;

- velikost črk jedrnega (tekočega) besedila je 11

- razmik med vrsticami 1,5 ;

Po smernicah UP PEF so naslovi poglavij:

- prve ravni velikosti 14 in zapisani z velikimi odebeljenimi črkami,

- naslovi poglavij druge ravni so velikosti 12 in zapisani z malimi odebeljenimi črkami,

- naslovi poglavij tretje ravni so velikosti 12 in zapisani z malimi odebeljenimi črkami v poševnem tisku,

- naslovi poglavij četrte ravni pa so v velikosti 12 in zapisani z malimi črkami v poševnem tisku.

Primer: 1 NASLOV, 1.1 Naslov, 1.1.1 Naslov, 1.1.1.1 Naslov;

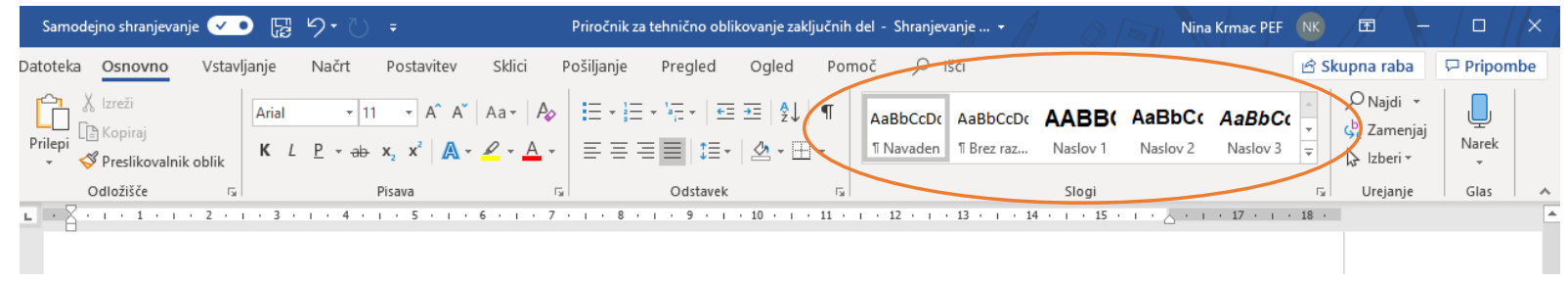

Slika 1: Slogi v Word dokumentu

To storimo v razdelku Slogi, označenem na sliki. Slog pisave lahko ločeno nastavimo za besedilo ter za posamezna poglavja. $V$ vašem primeru so pomembne nastavitve tako besedila kot vsake ravni poglavja, saj smernice UP PEF določajo različen slog pisave za vsak naslov poglavja posebej. S klikom na desno tipko na miški izberemo možnost Spremeni in nastavimo slog pisave, ki ga želimo oziroma je zahtevan.

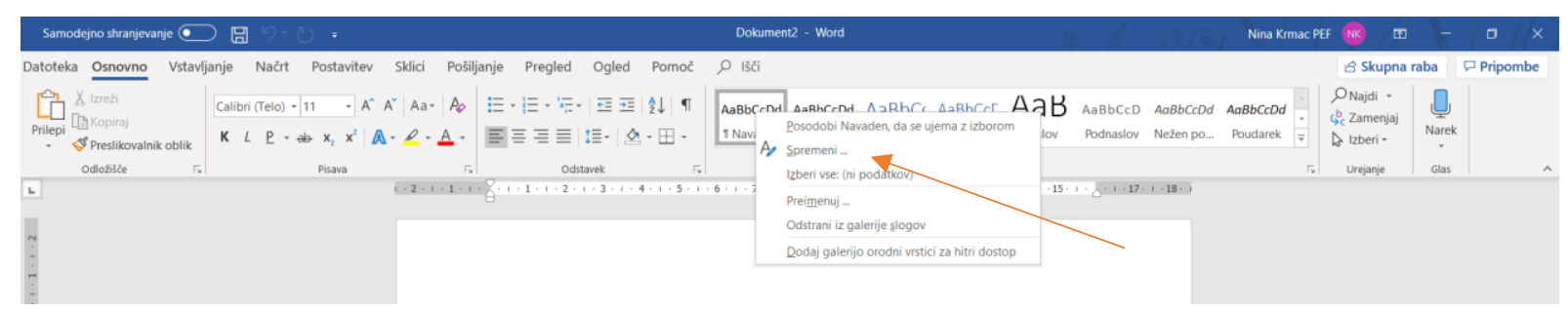

Slika 2: Sprememba nastavitev slogov 
Pred pričetkom dela $v$ dokumentu je pomembno, da te značilnosti pisave, ki so določene, nastavimo za tekoče besedilo (Navaden slog) ter ločeno še za poglavja prve, druge, tretje in četrte ravni.

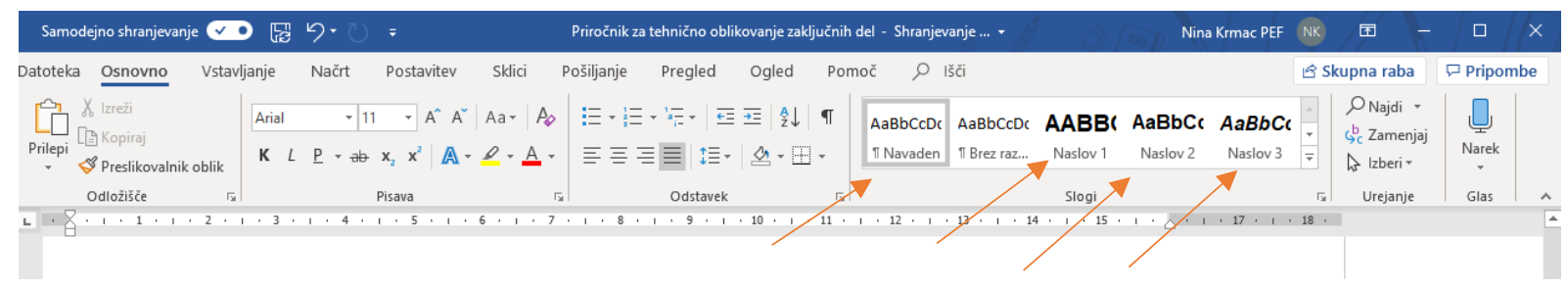

Slika 3: Osnovno oblikovanje tekočega besedila in poglavij

Miško postavimo na slog, ki ga želimo spremeniti, in kliknemo na desni gumb na miški. Prikaže se nam manjše okno in izberemo Spremeni.

S klikom na Spremeni se nam prikaže naslednje pogovorno okno:

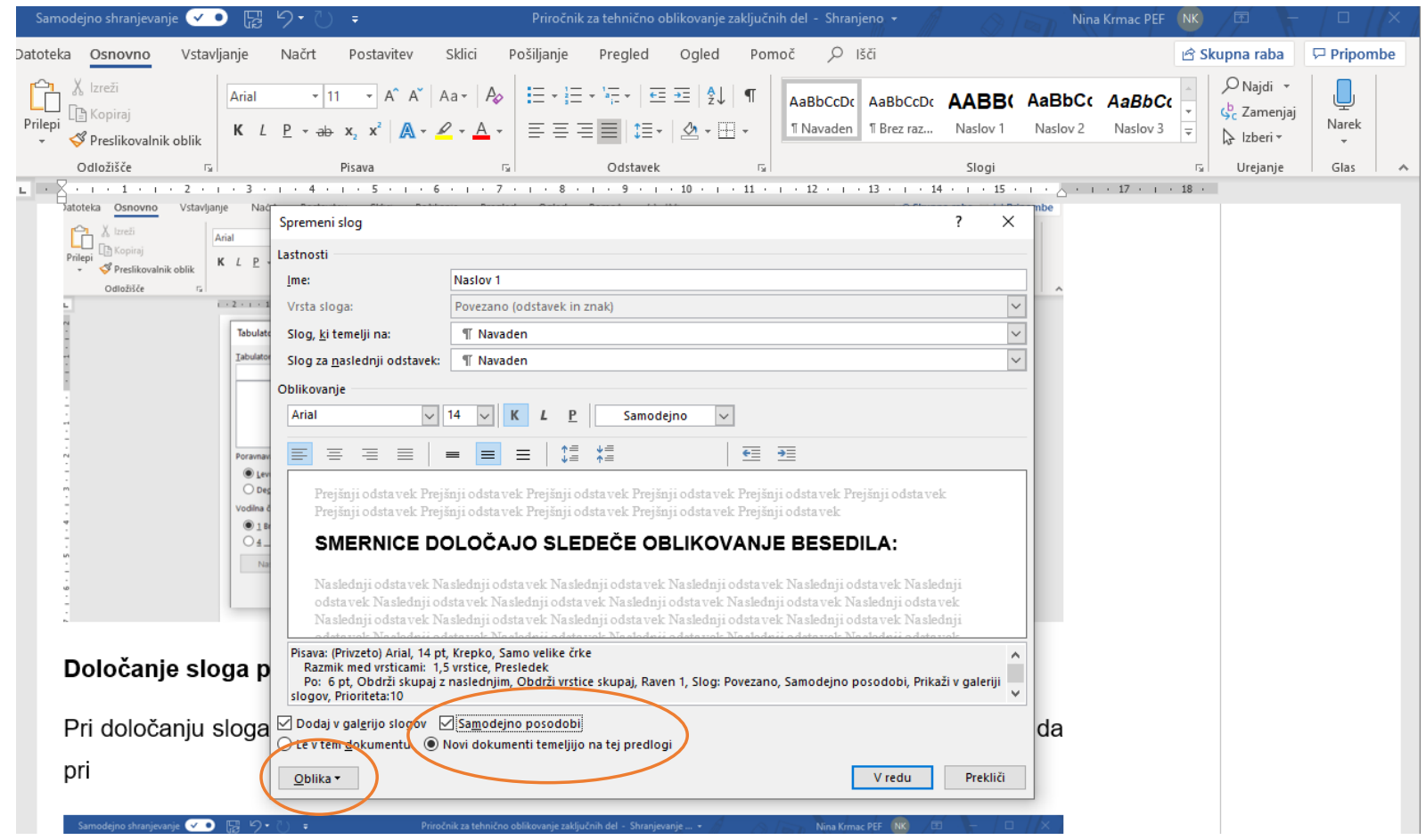

Slika 4: Osnovne nastavitve slogov

Dodatne možnosti za oblikovanje pisave se nahajajo pod Oblika (gumb levo spodaj) > Odstavek. Dobro je tudi označiti Novi dokumenti temeljijo na tej osnovi, ker bomo tako sloge za oblikovanje imeli shranjene za vse prihodnje dokumente, ter odkljukati možnost Samodejno posodobi. Vsi naslovi oziroma besedilo, ki je bilo označeno z določenim slogom, bo z ukazom Samodejno posodobi spremenilo slog, tako kot smo ga določili. 


\subsection{Določanje sloga tekočemu besedilu}

Sprotne nastavitve oziroma spremembe nastavitev se nahajajo pod zavihkom Osnovno > Odstavek (Do nastavitev odstavka dostopamo tudi z desnim klikom na odstavek in izberemo Odstavek $\overline{\overline{\overline{=}}}$.

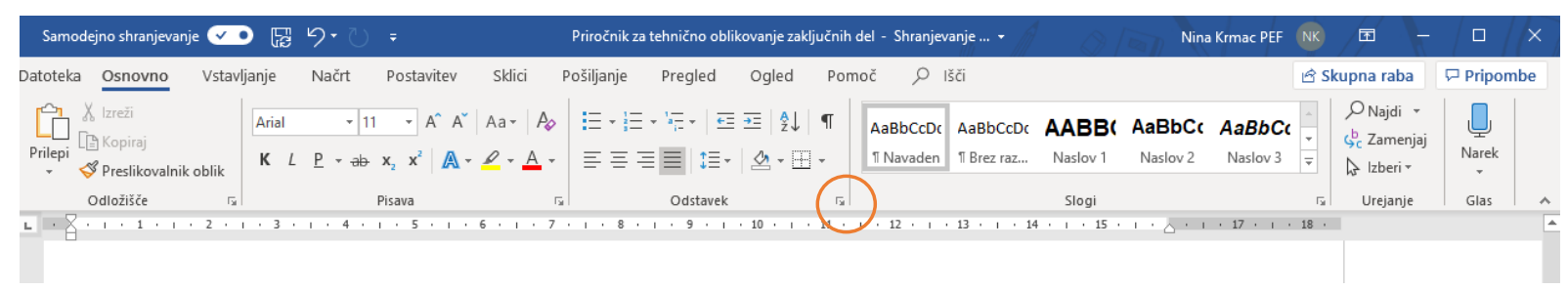

Slika 5: Odstavek

Po kliku na

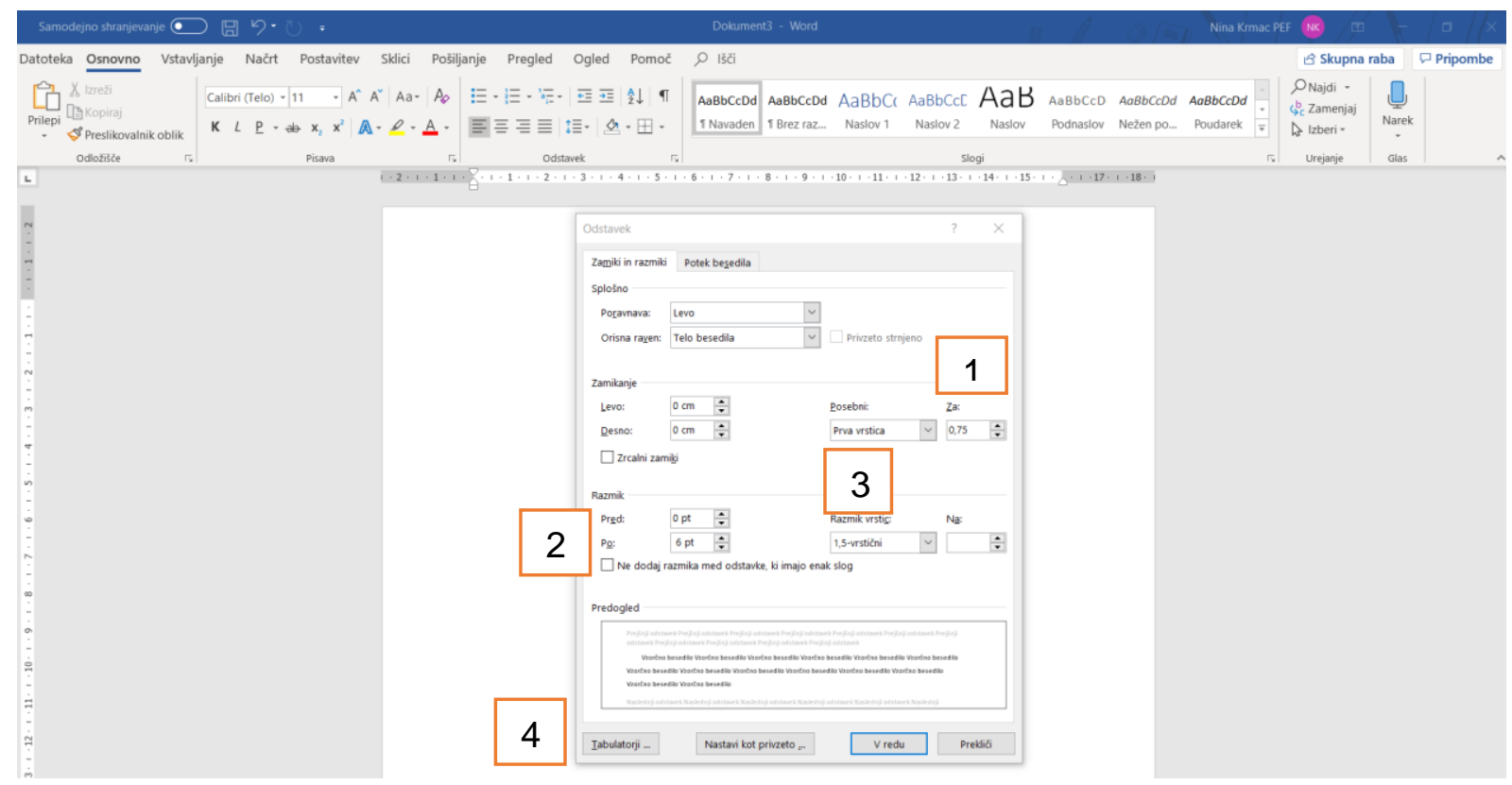

Slika 6: Določanje sloga tekočemu besedilu

Smernice določajo naslednje oblikovanje besedila:

- jedrno (tekoče) besedilo, zapisano v poglavjih in podpoglavjih, je členjeno v odstavke, prva vrstica odstavka se začne z zamikom $v$ desno za $0,75 \mathrm{~cm}$.

Kolikšen je zamik, zapišemo v okence, označeno s številom 1. Pomembno je tudi, da pri oknu Posebni izberemo Prva vrstica.

Smernice določajo tudi zamik po odstavku 6 pt., razen v kazalih (število 2 na sliki).

Določen je razmik 1,5 med vrsticami, ki ga lahko nastavimo v oknu Odstavek (število 3). 
Zamik $v$ desno je mogoče ročno nastaviti tudi $s$ tabulatorjem. Če kliknemo na gumb Tabulatorji (število 4), lahko v polju Privzeta tab. mesta označimo, da ima tabulator vedno zamik $0,75 \mathrm{~cm}$ v desno.

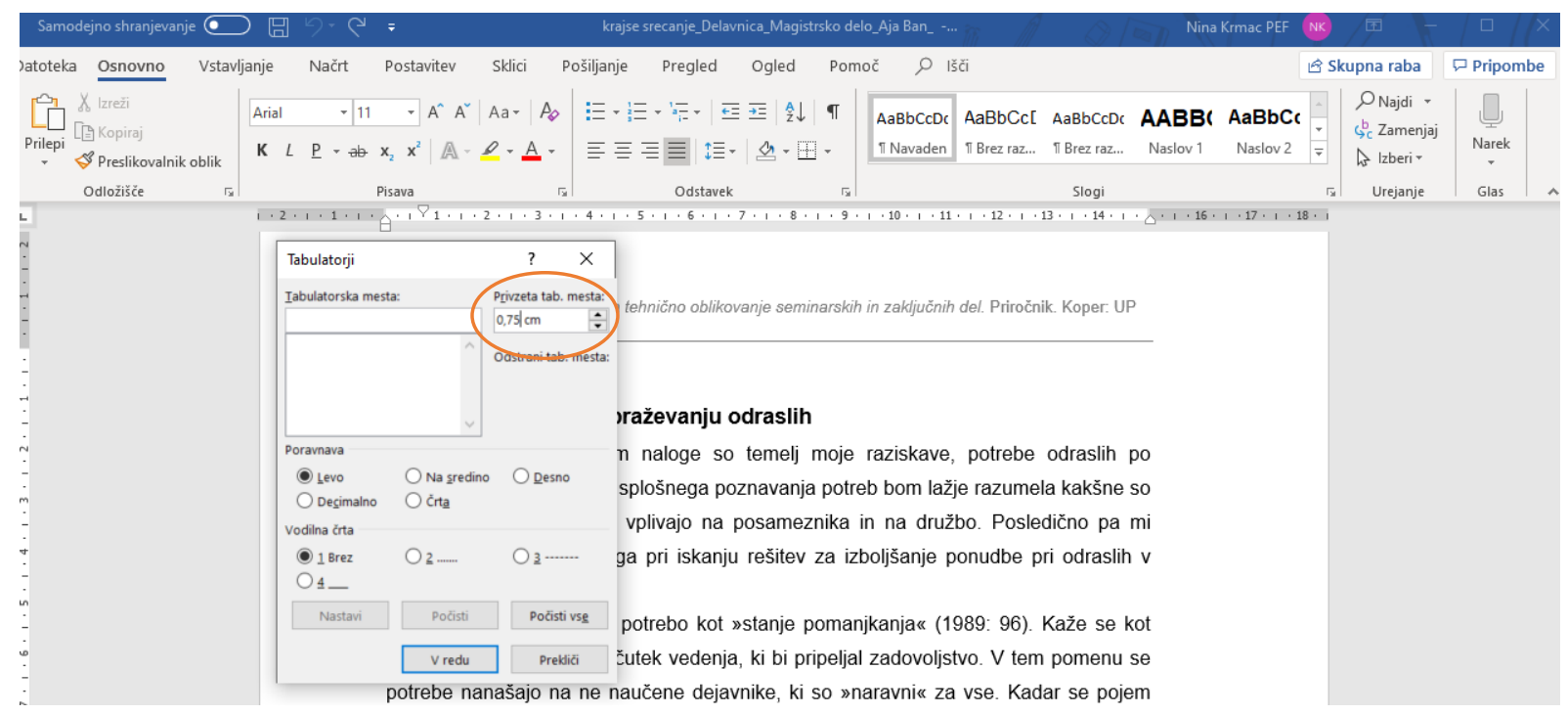

Slika 7: Zamik v desno

\subsection{Določanje sloga poglavij}

Pri določanju sloga poglavij je potek nastavitev skorajda enak. Pozorni moramo biti le, da pri poglavjih nimamo zamika $v$ desno, torej mora biti vrednost v polju Za: $0 \mathrm{~cm}$, kot je razvidno iz spodnje slike.

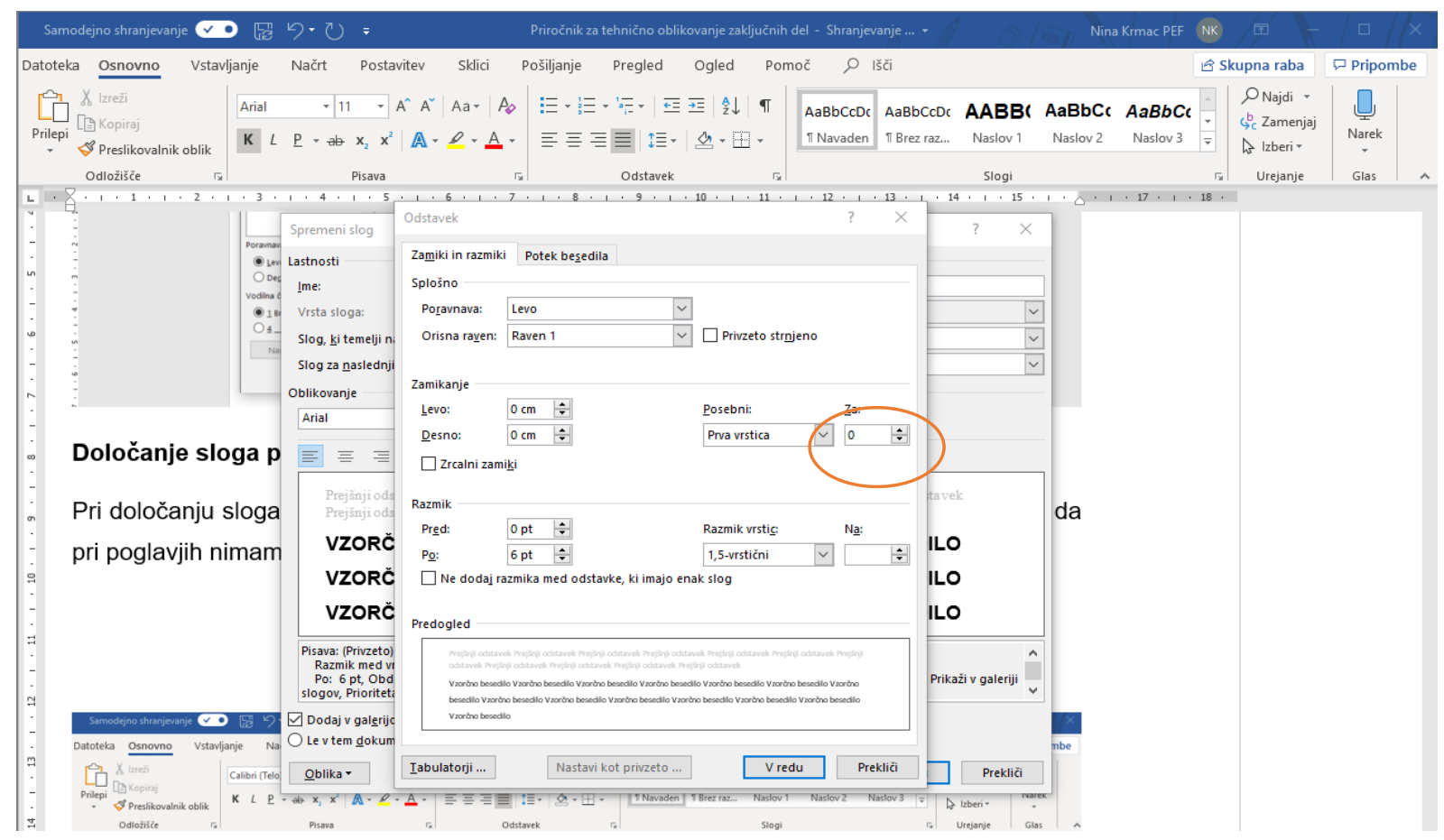

Slika 8: Določanje sloga poglavjem 
Pri Naslovu 1 so za prvo raven poglavja predpisane velike tiskane črke, to lahko označimo že pri gumbu Oblika, možnost Pisava (označeno na sliki).

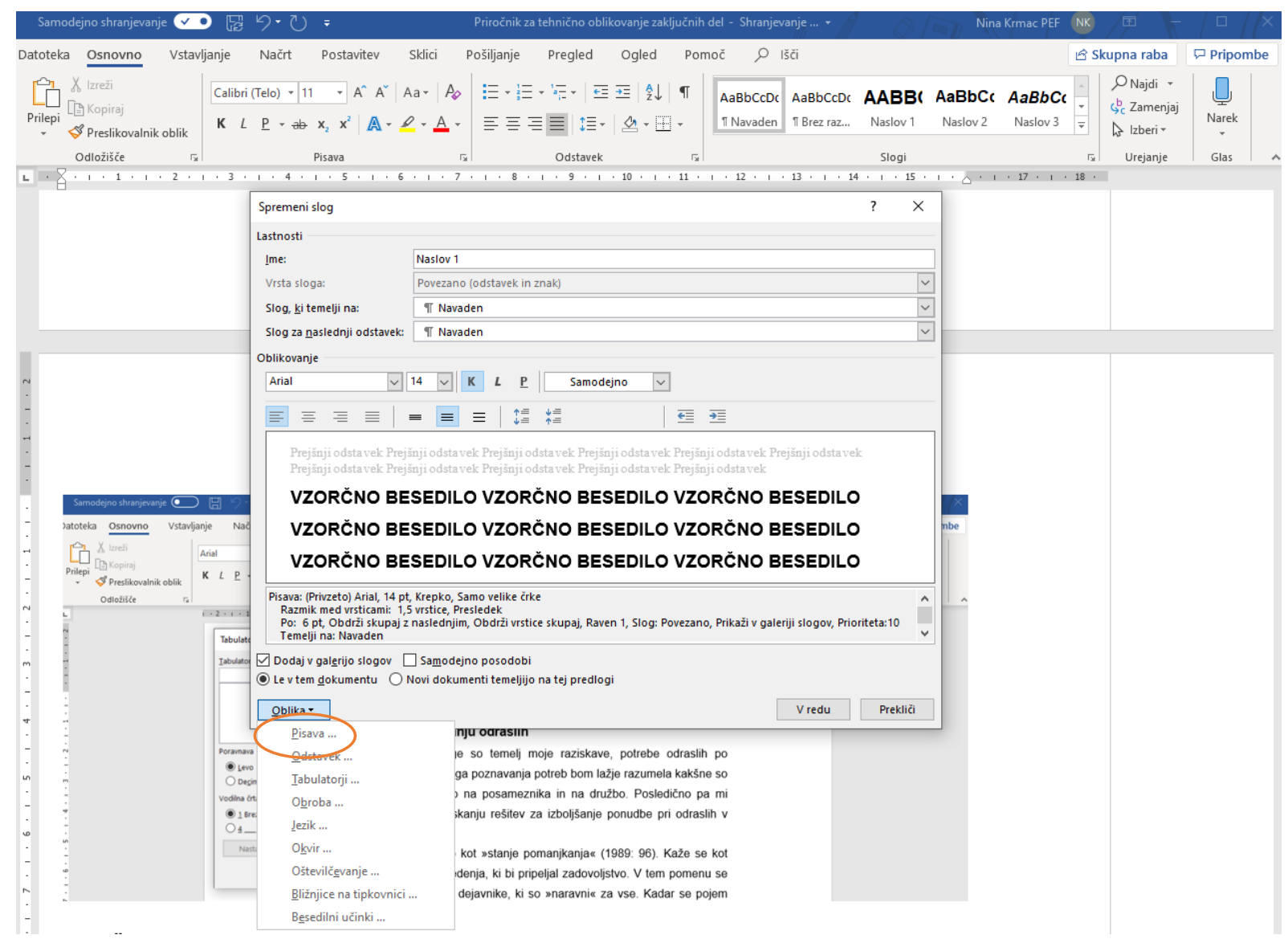

Slika 9: Oblikovanje pisave besedila za določen slog

S tem, ko nastavimo vse sloge, kot so določeni med pisanjem besedila, naslov poglavja le označimo in kliknemo na slog, ki je predpisan za to raven poglavja. Označen naslov poglavja bo pridobil značilnosti sloga, ki smo jih določili. Hkrati se nam bo v ozadju oblikovalo tudi samodejno kazalo. Več o tem je napisanega v poglavju Kazalo vsebine.

Za boljšo preglednost dokumenta predlagamo, da vsem slogom, ki so oblikovani za naslove poglavij, nastavimo tudi razmik pred odstavkom. $\mathrm{V}$ tem dokumentu je razmik pred odstavkom za poglavja 18 pt. Razmik pred odstavkom je za naslove poglavij lahko poljubno nastavljen. Naslovi poglavij so tako nekoliko ločeni od ostalega besedila in razmiki poglavij so $v$ celotnem besedilu samodejno usklajeni. 


\subsection{Določanje sloga naslovom ponazoril}

Tudi naslovom ponazoril (sem spadajo npr. slike, preglednice in grafi) lahko nastavimo slog, kar bistveno olajša čas urejanja, ko oblikujemo napise in samodejno kazalo ponazoril (glej poglavje Oblikovanje ponazoril). Kot je razvidno iz spodnje slike, v slogu Napis oblikujemo naslove ponazoril.

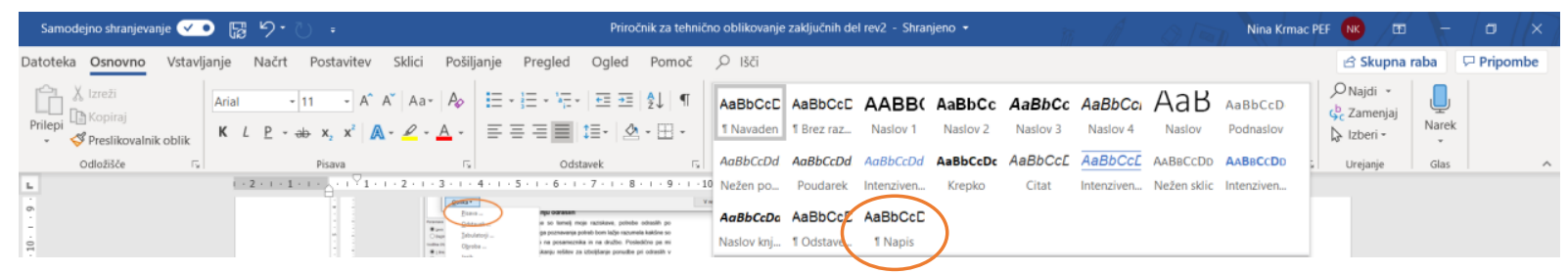

Slika 10: Slog ponazoril

Za boljšo preglednost je slogu ponazoril priporočeno nastaviti večji razmik po odstavku, kot je določen med tekočim besedilom. $V$ tem dokumentu je razmik po odstavku za naslove ponazoril 18 pt. Razmik po odstavku je za ponazorila lahko poljubno nastavljen.

\subsection{Ravnilo}

Ročno je zamik vrstice odstavka mogoče spreminjati tudi s pomočjo ravnila. Ravnilo nam je posebej v pomoč pri poravnavi določenega besedila. Ta poravnava je posebej potrebna pri prvi notranji strani zaključnega dela, saj smernice UP PEF določajo naslednjo obliko: 


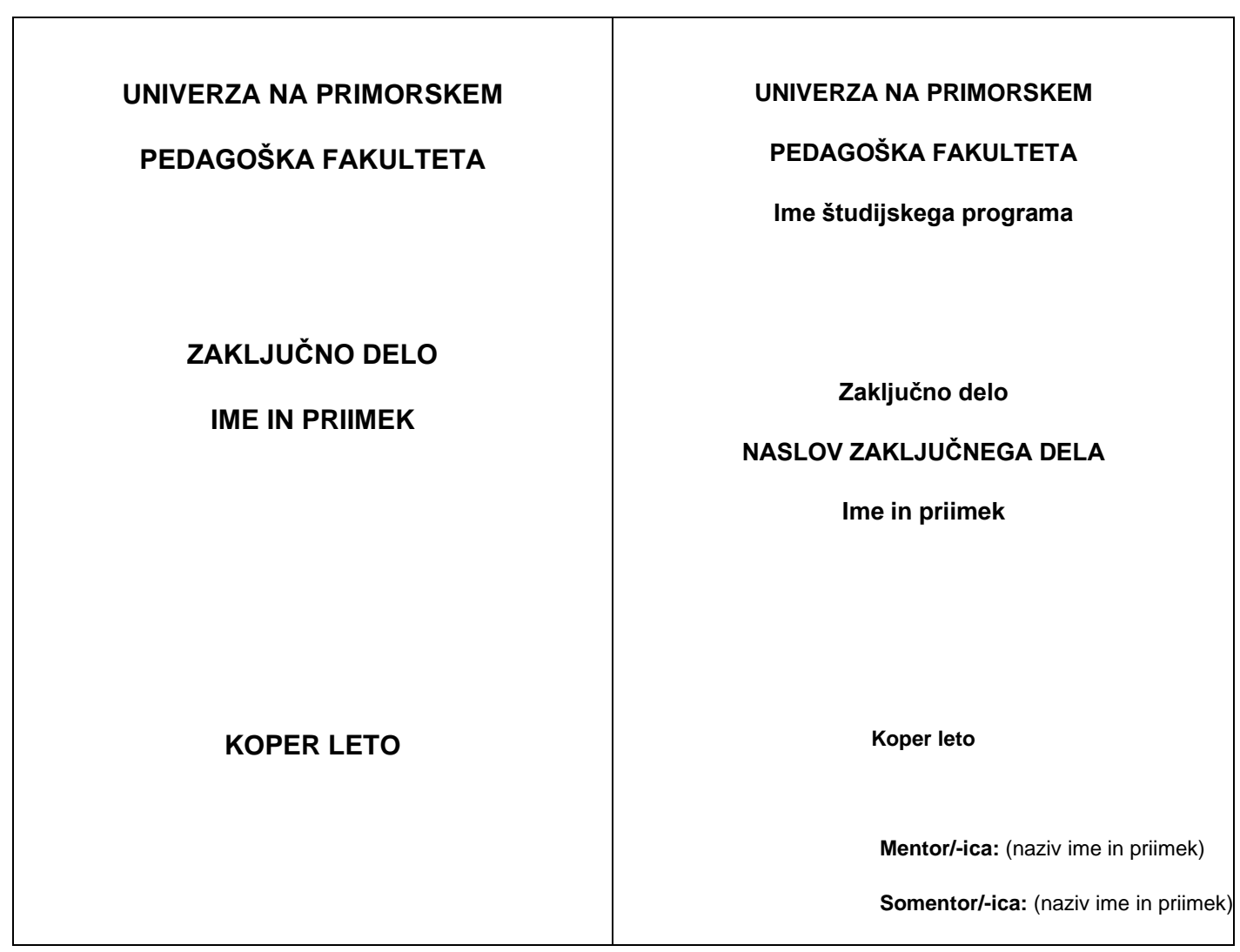

Slika 11: Platnica in prva notranja stran zaključnega dela (povzeto po Smernice za izdelavo zaključnih del, 2015, str. 4).

Kot določajo smernice, je pri prvi notranji strani (desna stran) Koper sredinsko poravnavan, Mentor in somentor pa nista sredinsko poravnana, ampak morata biti črki M (mentor) in S (somentor) vedno vzporedni s črto K (Koper).

To najlažje dosežemo z uporabo ravnila. Ravnilo vključimo v zavihku Ogled > Ravnilo.

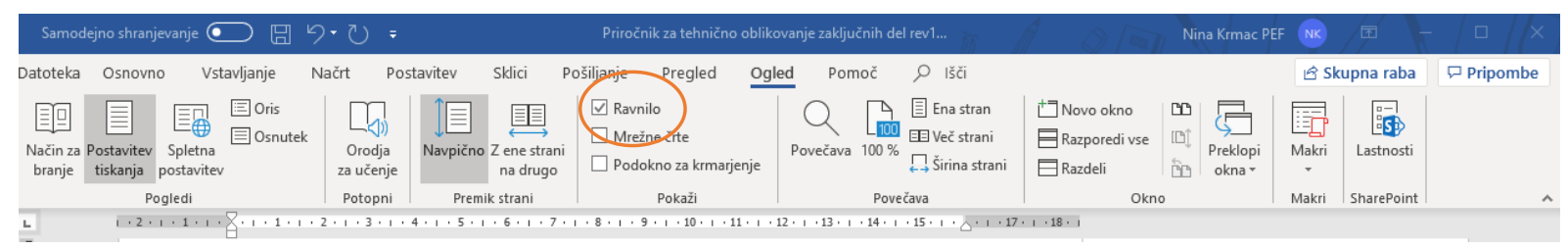

Slika 12: Vklop ravnila 
Krmac, Nina (2020). Priročnik za tehnično oblikovanje seminarskih in zaključnih del. Priročnik. Koper: UP PEF.

\section{Dokument3 - Word}

avitev Sklici Pošiljanje Pregled Ogled Pomoč $\rho$ Išči

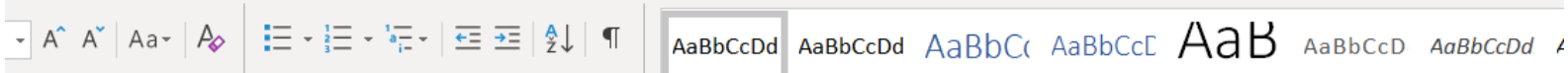

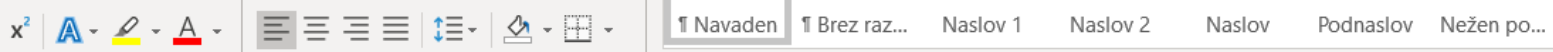

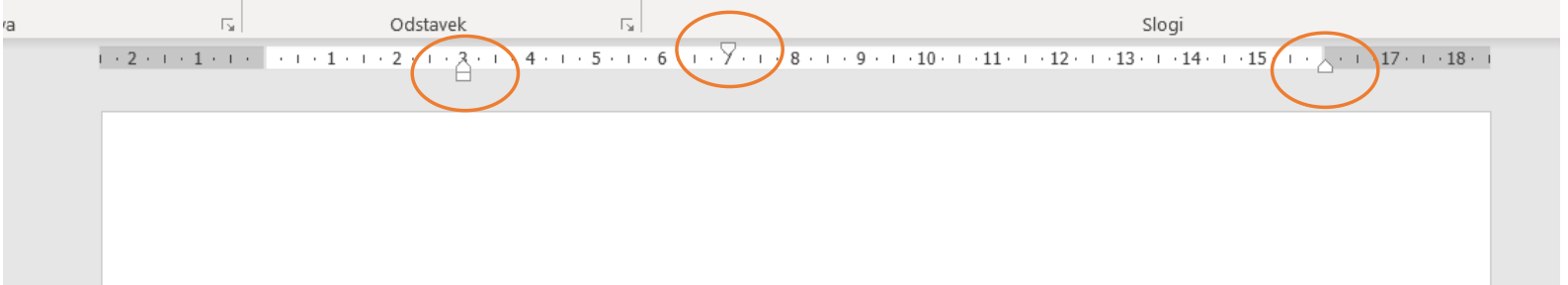

Slika 13: Prikaz ravnila

Pri ravnilu nam za poravnavo besedila pomagajo puščice, označene na sliki. $S$ premikanjem puščic $v$ levo ali desno poravnamo besedilo. 


\section{OBLIKOVANJE GLAVE IN NOGE}

Smernice UP PEF določajo poseben zapis in velikost pisave $v$ nogi in glavi besedila.

\subsection{Oblikovanje glave dokumenta}

Glava besedila, ki je ločena s črto, vsebuje navedbo avtorja, letnico nastanka zaključnega dela, naslov zaključnega dela, vrsto zaključnega dela, kraj, fakulteto. Glava besedila se zaključi s piko.

Primer: Krmac, Nina (2020). Priročnik za tehnično oblikovanje seminarskih in zaključnih del. Priročnik. Koper: UP PEF.

Za urejanje glave dokumenta najprej dvokliknemo v prostor glave besedila. Vanj napišemo besedilo in ga uredimo, kot določajo smernice UP PEF. Velikost črk glave je 9. Naslov ležeče. Črto pod besedilom pa naredimo s pomočjo Osnovno > Odstavek >

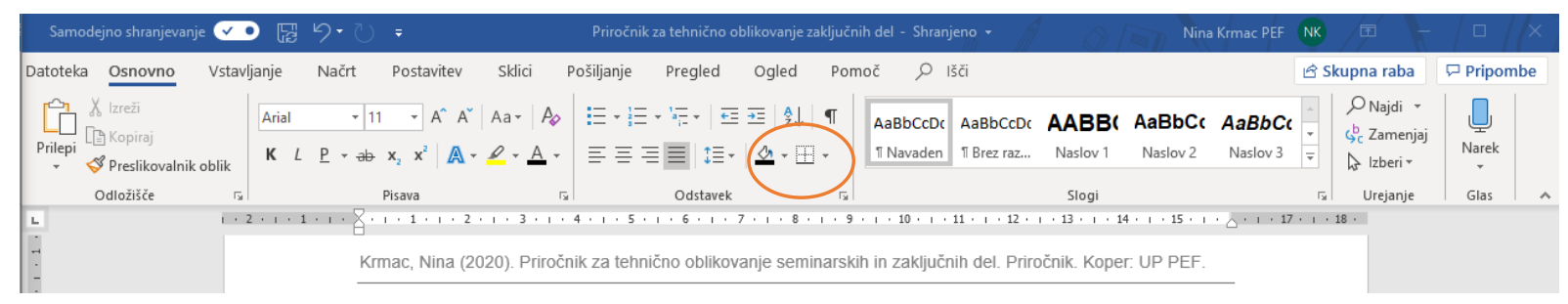

Slika 14: Oblikovanje glave dokumenta

Če dvokliknemo z miško na mesto glave ali noge besedila, postaneta aktivni tako noga kot glava in ju je mogoče oblikovati.

\subsection{Oblikovanje noge dokumenta}

Smernice UP PEF določajo naslednje:

- številka strani $v$ nogi mora biti od spodnjega roba oddaljena $1,5 \mathrm{~cm}$ in sredinsko poravnana;

- $\quad$ strani se številči od uvoda dalje;

- oštevilčen je tudi seznam virov in literature ter priloge.

Slednje storimo tako, da dvokliknemo v nogo in v Načrt > Položaj označimo Noga od dna $1,5 \mathrm{~cm}$. 


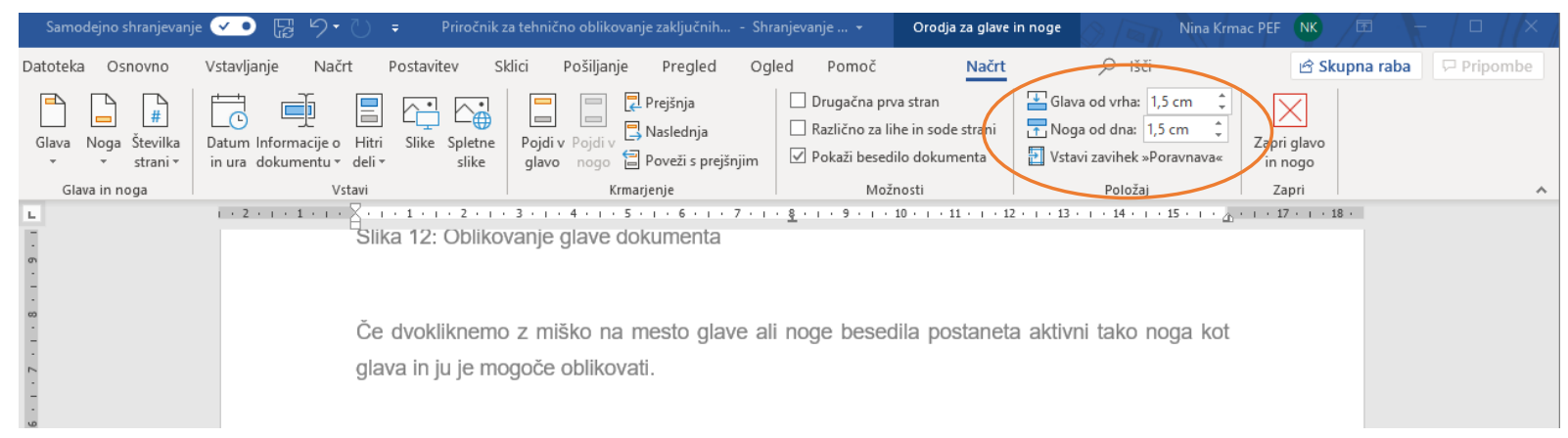

Slika 15: Oblikovanje noge dokumenta

\subsection{Prelom odseka}

Zaradi naslovne strani, kazal itd., je uvod prisoten npr. na 10. strani, mi pa ga želimo oštevilčiti kot stran 1. To storimo tako, da miško postavimo pred besedo Uvod (1 UVOD), kliknemo na zavihek Postavitev in kliknemo na puščico obrnjeno navzdol pri besedi Prelomi. Pod Prelomi odseka izberemo ukaz Naslednja stran.

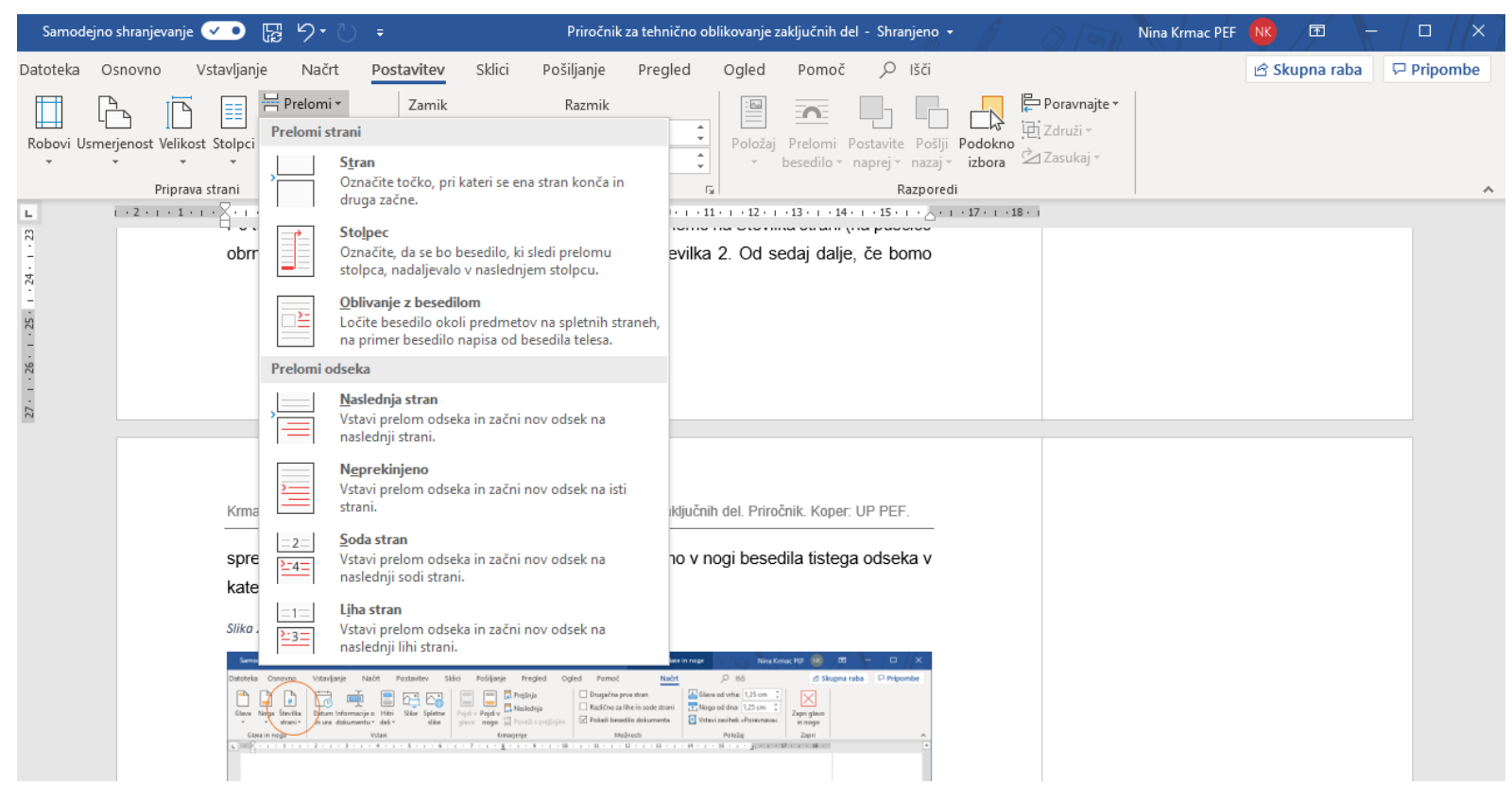

Slika 16: Prelom odseka

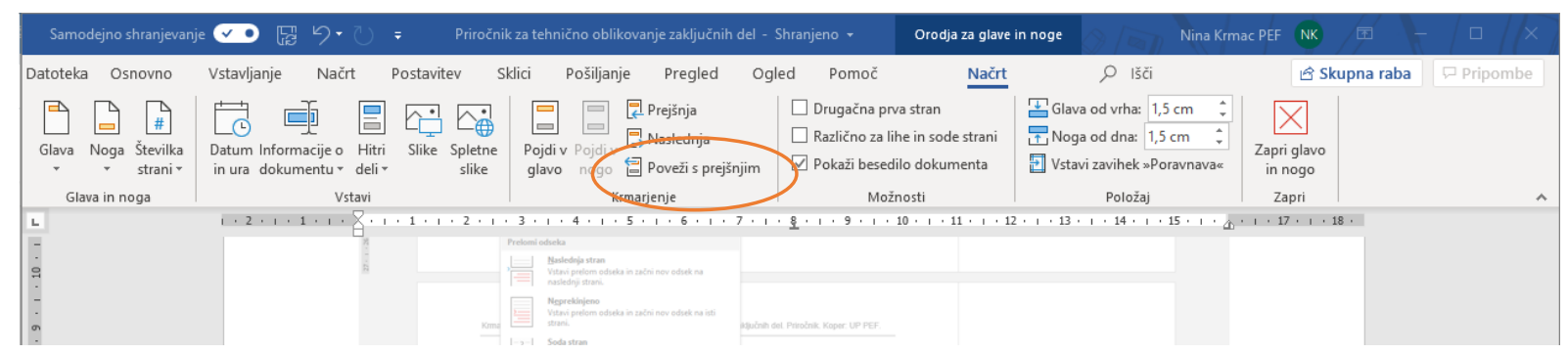

Slika 17: Poveži s prejšnjim 
Če bomo od zdaj naprej spreminjali besedilo v nogi, se bo besedilo spreminjalo samo v nogi besedila tistega odseka, v katerem smo besedilo spreminjali.

\section{4 Številčenje strani}

Po tem, ko smo odznačili ukaz Poveži s prejšnjim, lahko kliknemo na Načrt > Številka strani (na puščico obrnjeno navzdol) in izberemo Dno strani > Navadna številka 2.

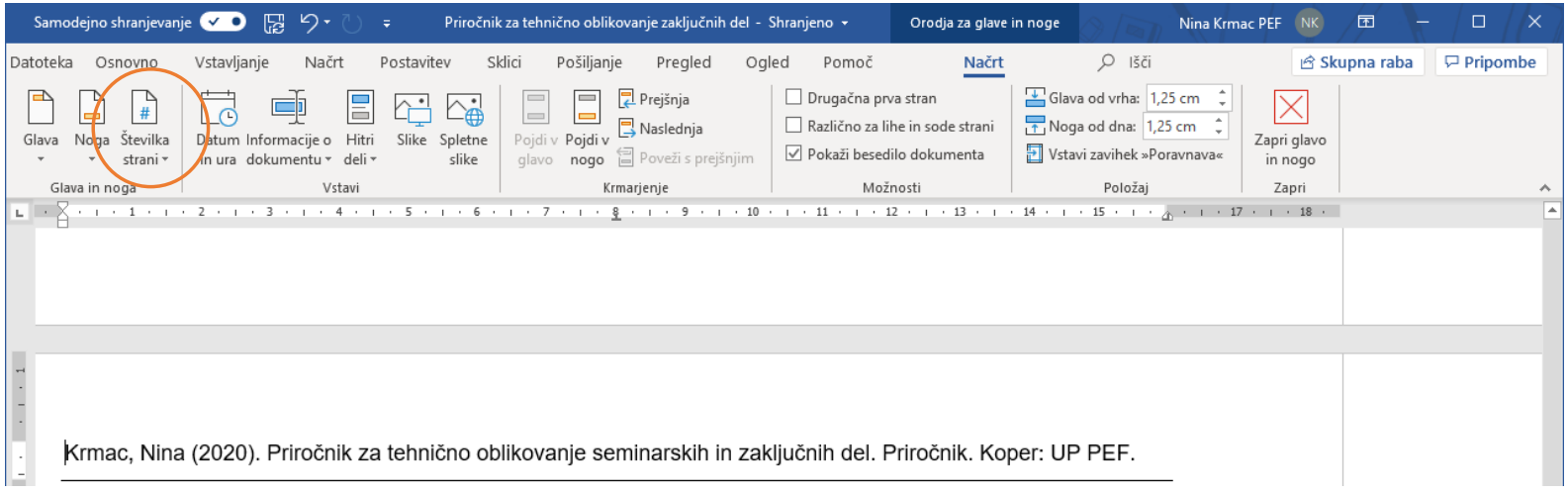

Slika 18: Številčenje strani

Ne smemo pozabiti, da je potrebno enako nastaviti tudi v glavi besedila. Smernice UP PEF namreč določajo, da je besedilo v glavi prisotno le od Uvoda dalje. Popolnoma enako naredimo za glavo, torej dvokliknemo v glavo in odznačimo ukaz Poveži s prejšnjim.

Četudi smo za tekoče besedilo označili pisavo Arial in razmik med vrsticami 1,5 , te nastavitve ne veljajo za prostor, ki se nahaja v nogi in glavi besedila. Zato je pomembno, da ne pozabimo tako v nogi kot glavi besedila določiti besedilu pisavo Arial ter velikost pisave in razmik med vrsticami, ki sta predpisana. Tudi v nogi in glavi je razmik med vrsticami 1,5.

\subsection{Prelom strani}

Trenutno smo uporabili prelom odseka. $V$ veliko pomoč nam je lahko tudi prelom strani. Smernice UP PEF določajo, da morajo naslovi prvih ravni stati vedno ločeno na novi strani. Torej uvod, teoretični del itd. Enako velja tudi Kazalo vsebine. Da bodo naslovi prvih ravni vedno samodejno na prvi strani, ne glede na besedilo, ki ga pred in po tem naslovu pišemo, v nastavitvah sloga za naslove prvih ravni kliknemo na Oblika > Odstavek > Potek besedila > Prelomi stran pred. 


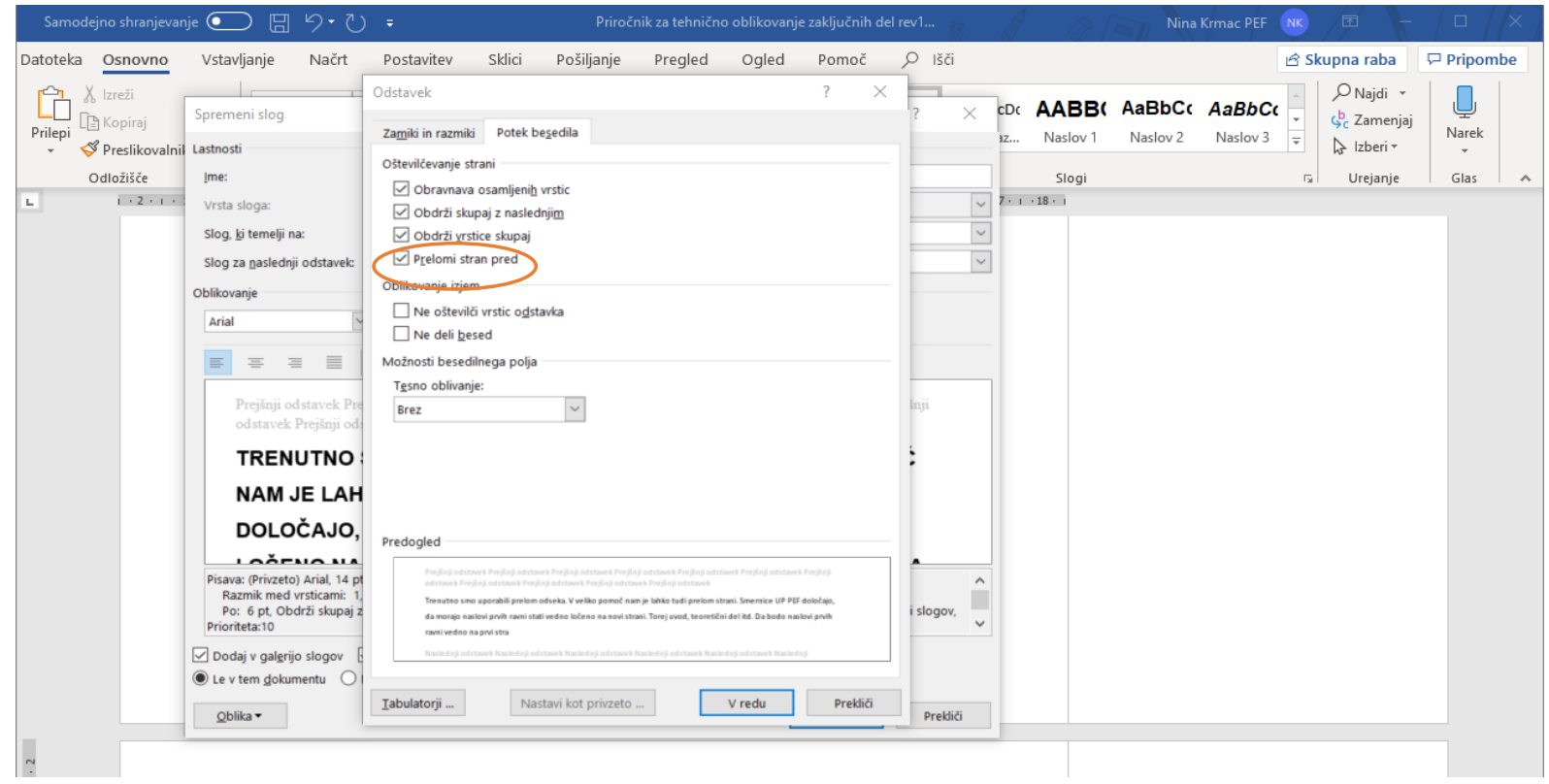

Slika 19: Prelom strani za prve ravni

Če želimo na določenem delu besedila ročno postaviti prelom stani, to storimo, kot je prikazano na spodnji sliki. To storimo tako, da miško postavimo pred naslov poglavja, za katerega želimo, da vedno stoji ločeno na svoji strani in izberemo Postavitev > Prelomi > Stran.

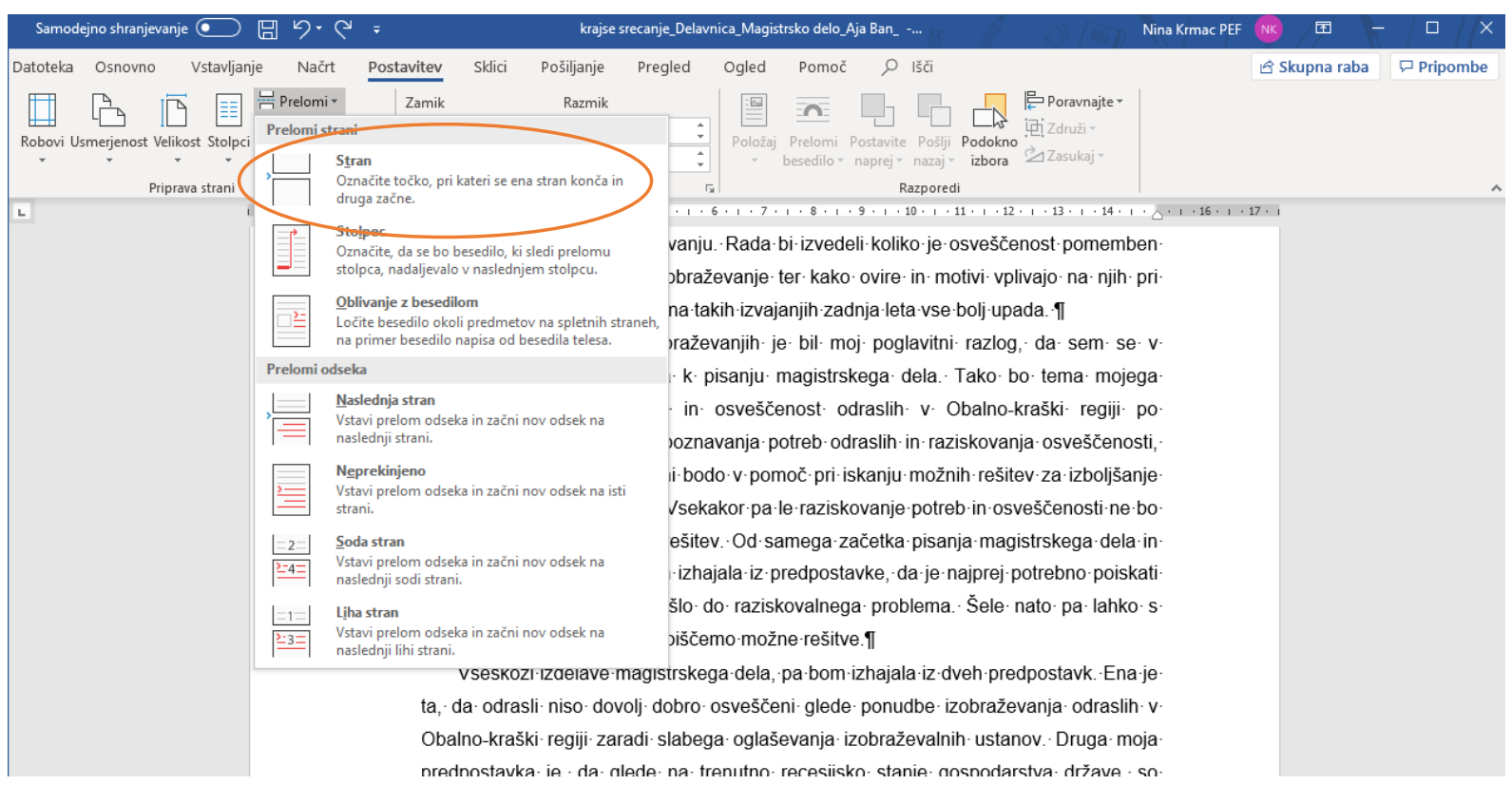


Slika 20: Prelom strani

\subsection{Zrcalni robovi}

V zavihku postavitev ne pozabimo nastaviti tudi robove. Smernice UP PEF določajo, da morajo biti zunanji, zgornji in spodnji robovi $2,5 \mathrm{~cm}$, notranji robovi pa $3,5 \mathrm{~cm}$ ter dodatno zrcalni robovi od uvoda dalje. Te smernice so tako določene zaradi obojestranskega tiska in potrebnega roba za vezavo zaključnega dela.

Pri zrcalnih robovih je potrebno paziti, da imamo že predhodno nastavljene prelome odsekov ter da prelomi med seboj niso povezani. Zato je zrcalne robove najbolje nastaviti po tem, ko nastavimo številke stranem od uvoda dalje.

Zrcalne robove se oblikuje na naslednji način:

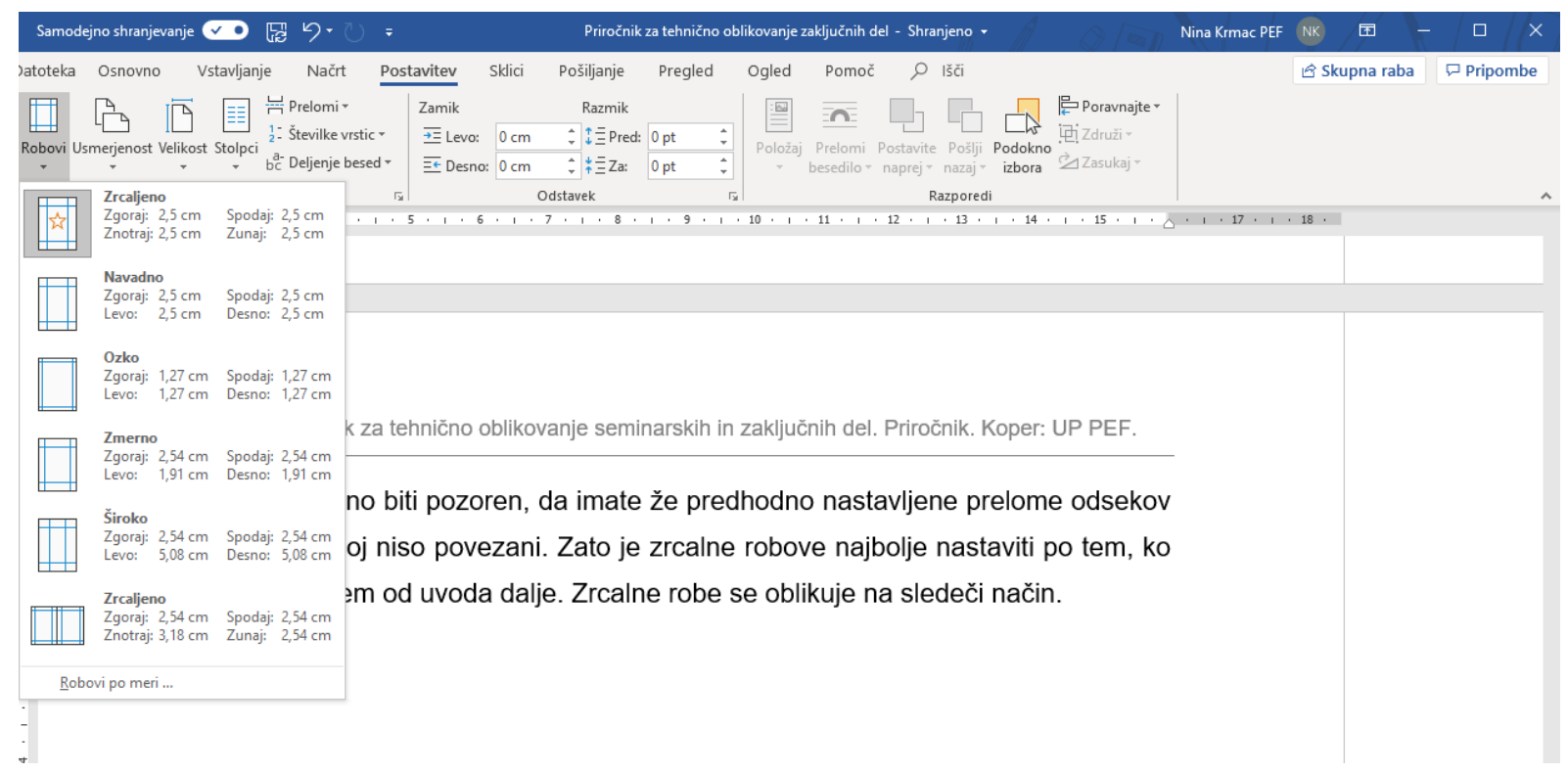

Slika 21: Robovi 
Najprej kliknemo na zavihek Postavitev in nato Robovi ter izberemo Robovi po meri. Prikaže se nam naslednje pogovorno okno.

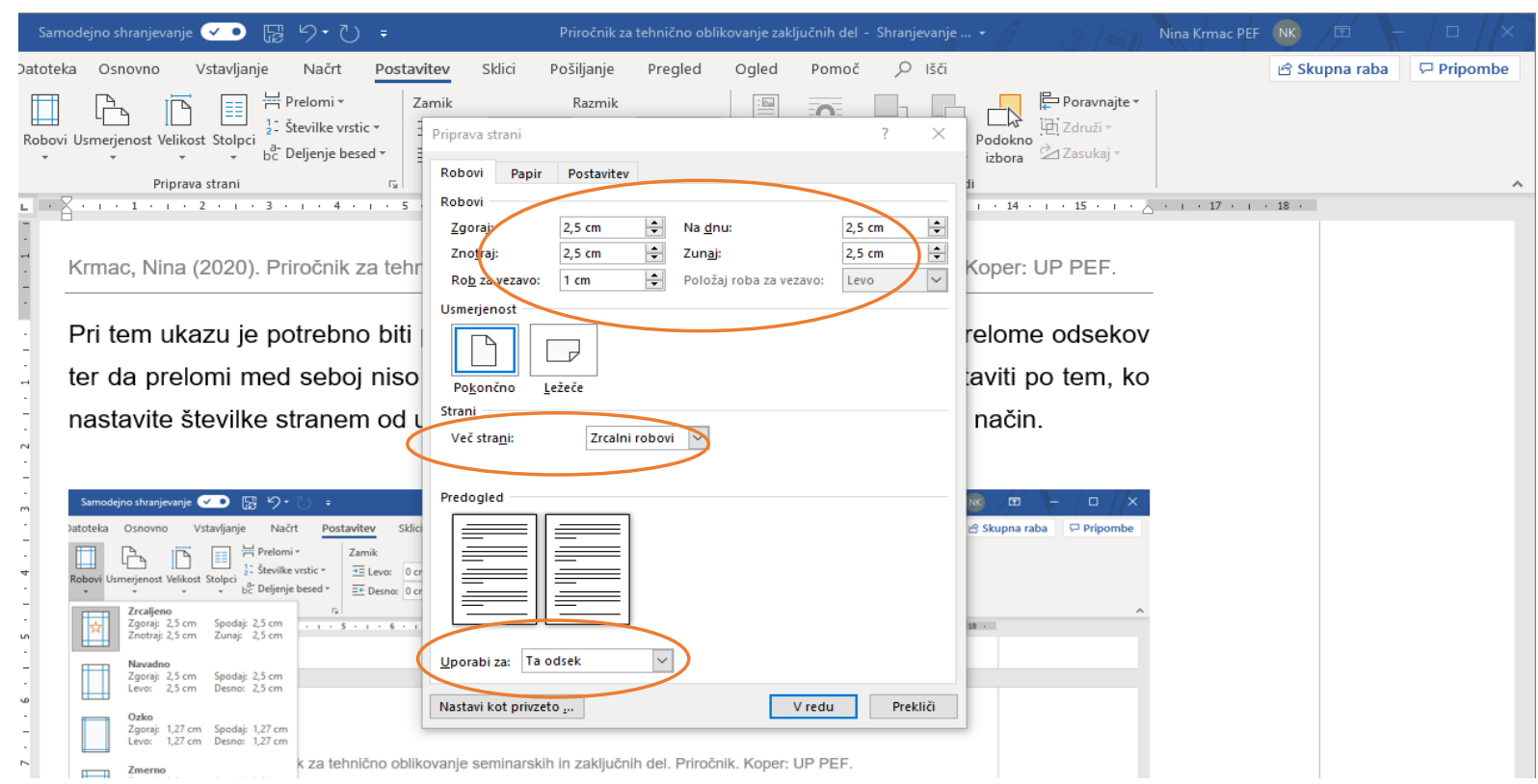

Slika 22: Zrcalni robovi

$V$ tem oknu je pomembno, da označimo vse robove $2,5 \mathrm{~cm}$, četudi smernice UP PEF določajo notranji rob $3,5 \mathrm{~cm}$. Pri Rob za vezavo pa napišemo $1 \mathrm{~cm}$. Pod Več strani izberemo Zrcalni robovi ter v razdelku Predogled pod Uporabi za: izberemo Ta Odsek. Na tak način bomo imeli zrcalne robove od uvoda dalje.

V kolikor imamo v dokumentu več odsekov, je bolje pod Uporabi za: izbrati možnost Od te točke naprej.

\subsection{Ležeča postavitev besedila}

Prelomi odseka lahko pridejo v poštev tudi, če želimo med pokončnimi listi postaviti nekaj listov v ležeči položaj. To pomeni, da moramo najprej nastaviti prelom odseka (Postavitev > Prelomi > Naslednja stran) na začetek besedila, ki ga želimo v ležečem položaju, ter za novo poglavje, kjer želimo strani povrniti nazaj v pokončno stanje. Dodati moramo dva preloma odseka, pred in po listih, ki jih želimo ležeče. Nato izberemo zavihek Postavitev > Usmerjenost > Ležeče. 


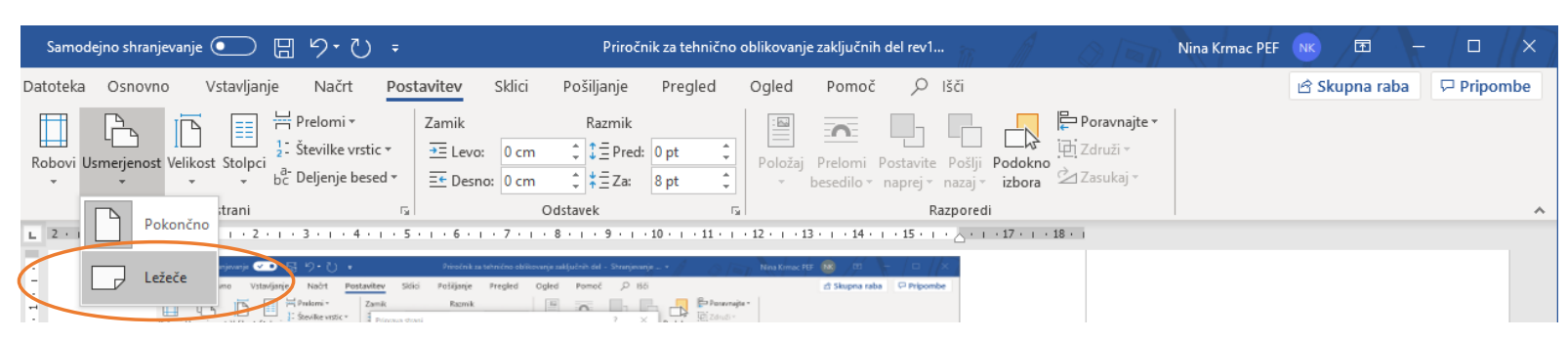

Slika 23: Postavitev ležeče

S tem, ko dodamo nove odseke, ki niso povezani z ostalimi odseki, se tudi številčenje strani in besedilo $v$ glavi ne bo nadaljevalo. To pomeni, da moramo na straneh, ki so ležeče postavljene in na naslednjem odseku dvoklikniti v nogo, klikniti Številka strani in izbrati Oblikuj številke strani. Prikazalo se bo pogovorno okno:

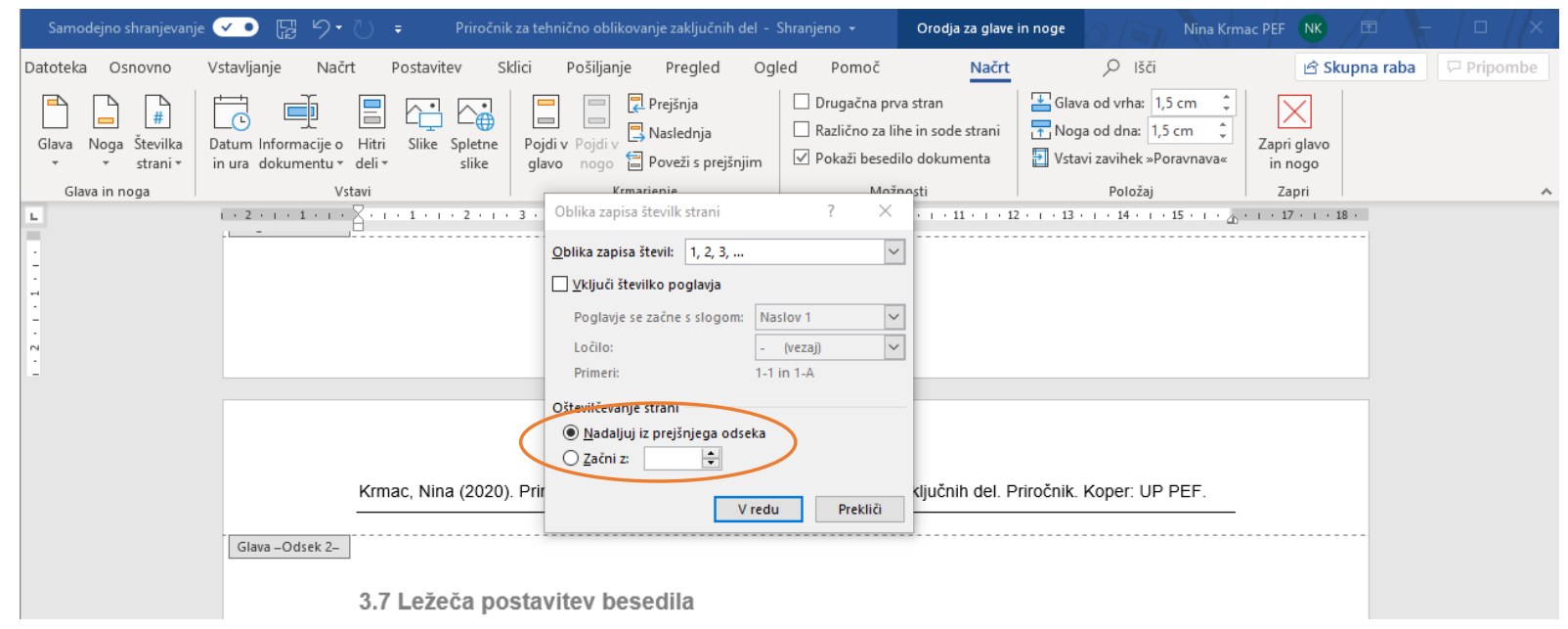

Slika 24: Ležeča postavitev besedila

Označimo Nadaljuj iz prejšnjega odseka. Enako naredimo na začetku strani, ki so postavljene ležeče in na začetku strani v nadaljevanju, ki so spet postavljene pokončno. 


\section{OBLIKOVANJE PONAZORIL}

Pri ponazorilih, kot so preglednice, grafi in slike, je mogoče samodejno oštevilčevanje, kar prinaša veliko prednost, večjo natančnost in velik prihranek časa.

Smernice UP PEF določajo, da morajo biti vsaka preglednica, slika ali graf oštevilčeni z arabsko številko in ustrezno naslovljeni.

Naslov preglednice pišemo zgoraj, naslov slike ali grafa pa spodaj.

Samodejno številčenje nastavimo tako, da miško postavimo nad preglednico ali sliko. Nato kliknemo na zavihek Sklici in poiščemo ukaz Vstavi napis.

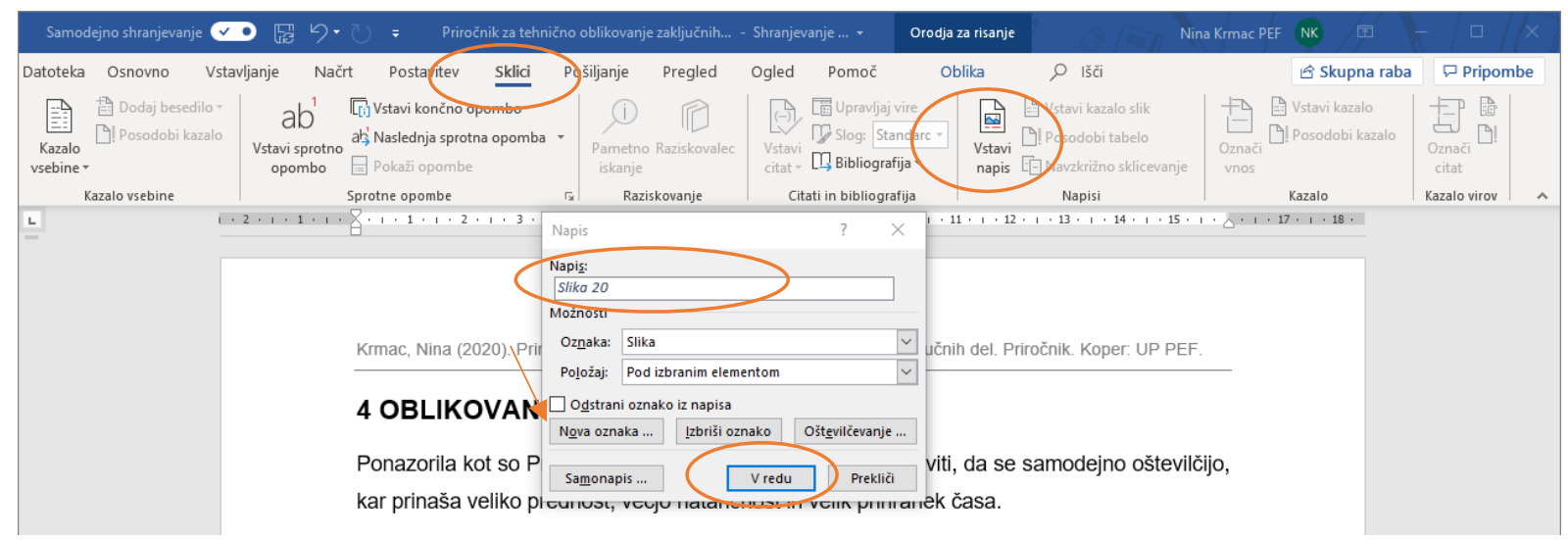

Slika 25: Oblikovanje samodejnega ponazorila

Če v polju Oznaka nimamo možnosti izbire Slika, jo oblikujemo sami tako, da levo spodaj kliknemo Nova Oznaka, napišemo Slika in nato kliknemo V redu. V polju Oznaka bo na voljo ponazorilo Slika. $\mathrm{V}$ polje Napis napišemo naslov slike in vsakič kliknemo $\mathbf{V}$ redu.

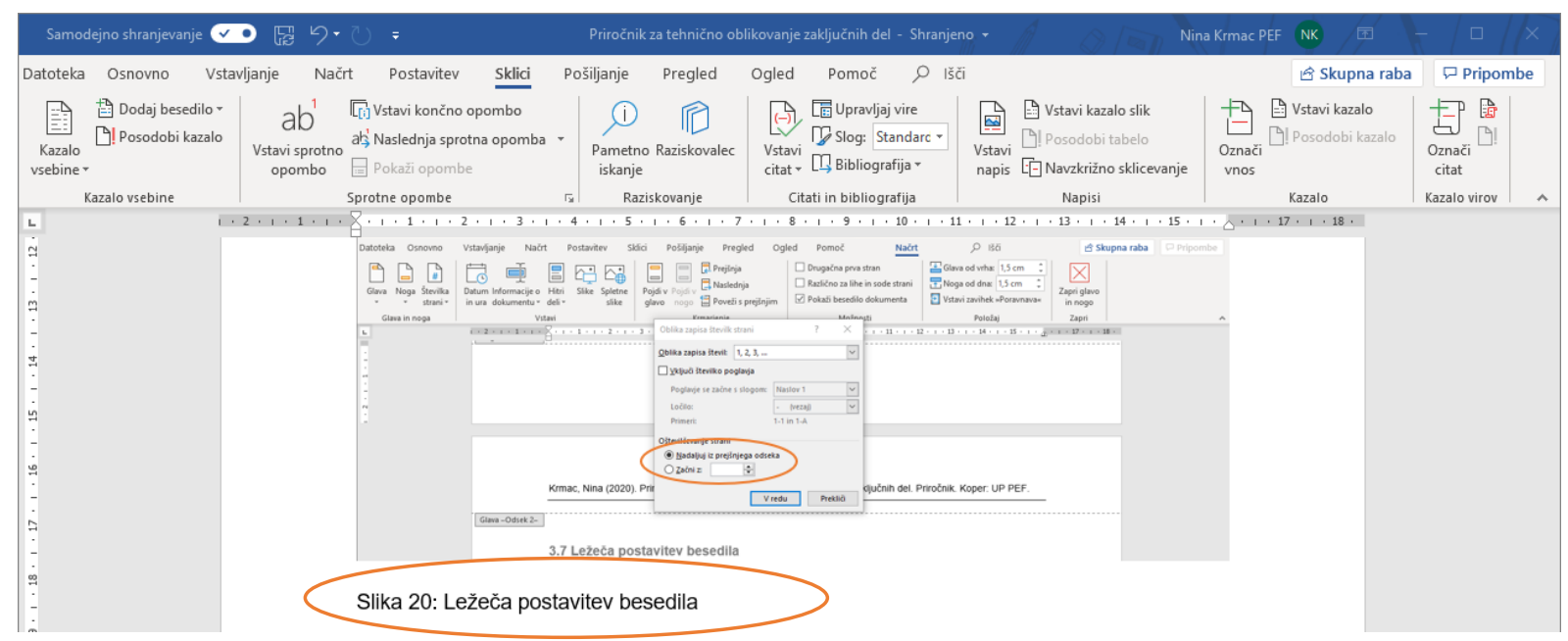

Slika 26: Sprememba naslova ponazorila 
Ko kliknemo V redu, se nam na mesto, kamor smo postavili miško (pod sliko), prikaže naslov slike.

@

Naslov slike lahko kasneje v besedilu tudi spreminjamo. Spremembe se bodo z osvežitvijo kazala prikazale v kazalu ponazorila.

Tudi po oblikovanju samodejnega kazala lahko dodajamo preglednice, ki bodo samodejno pravilno oštevilčene. Na enak način oblikujemo kazalo za slike in grafe, in sicer tako, da izberemo oznako Graf ali Slika, program pa bo v ozadju oblikoval tri različna kazala.

\subsection{Oblikovanje kazal}

Ko je delo zaključeno ali poljubno lahko tudi vmes (predvsem, če je delo zelo obsežno), oblikujemo kazalo vsebine, kazalo preglednic, grafov itd.

To storimo tako, da najprej miško postavimo na mesto, kjer želimo, da kazalo leži. Napišemo naslov Kazalo slik, postavimo miško pod naslov, kliknemo na Sklici in Vstavi kazalo slik.

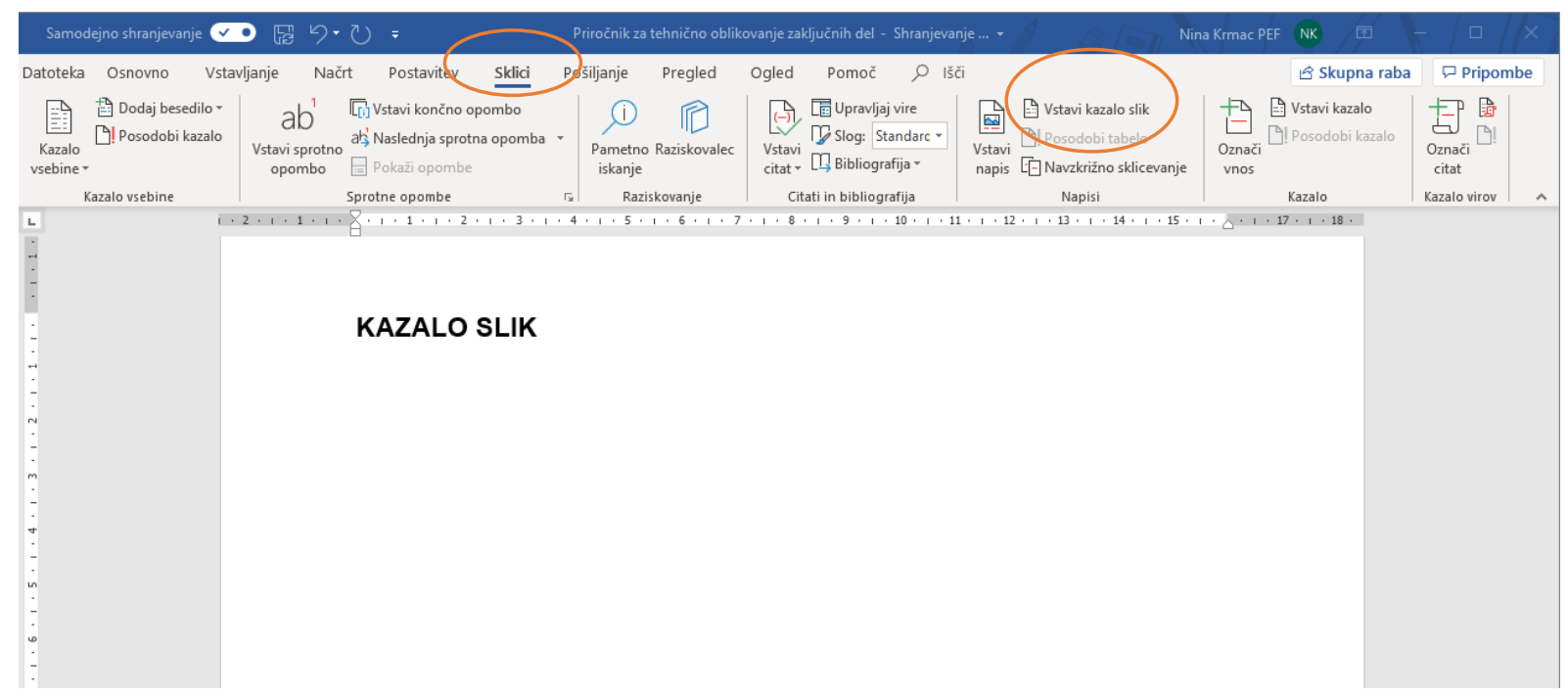

Slika 27: Vnos kazala slik

Odpre se nam pogovorno okno Kazalo slik. To okno ponuja vstavitev kazala slik, preglednic itd. Levo spodaj izberemo oznako, torej kazalo, ki ga želimo vstaviti, in kliknemo V redu. Prikaže se nam kazalo preglednic. Kot je razvidno iz spodnje slike, lahko kazalo tudi nekoliko oblikujete, izberemo lahko obliko, vodilno črto itd. 


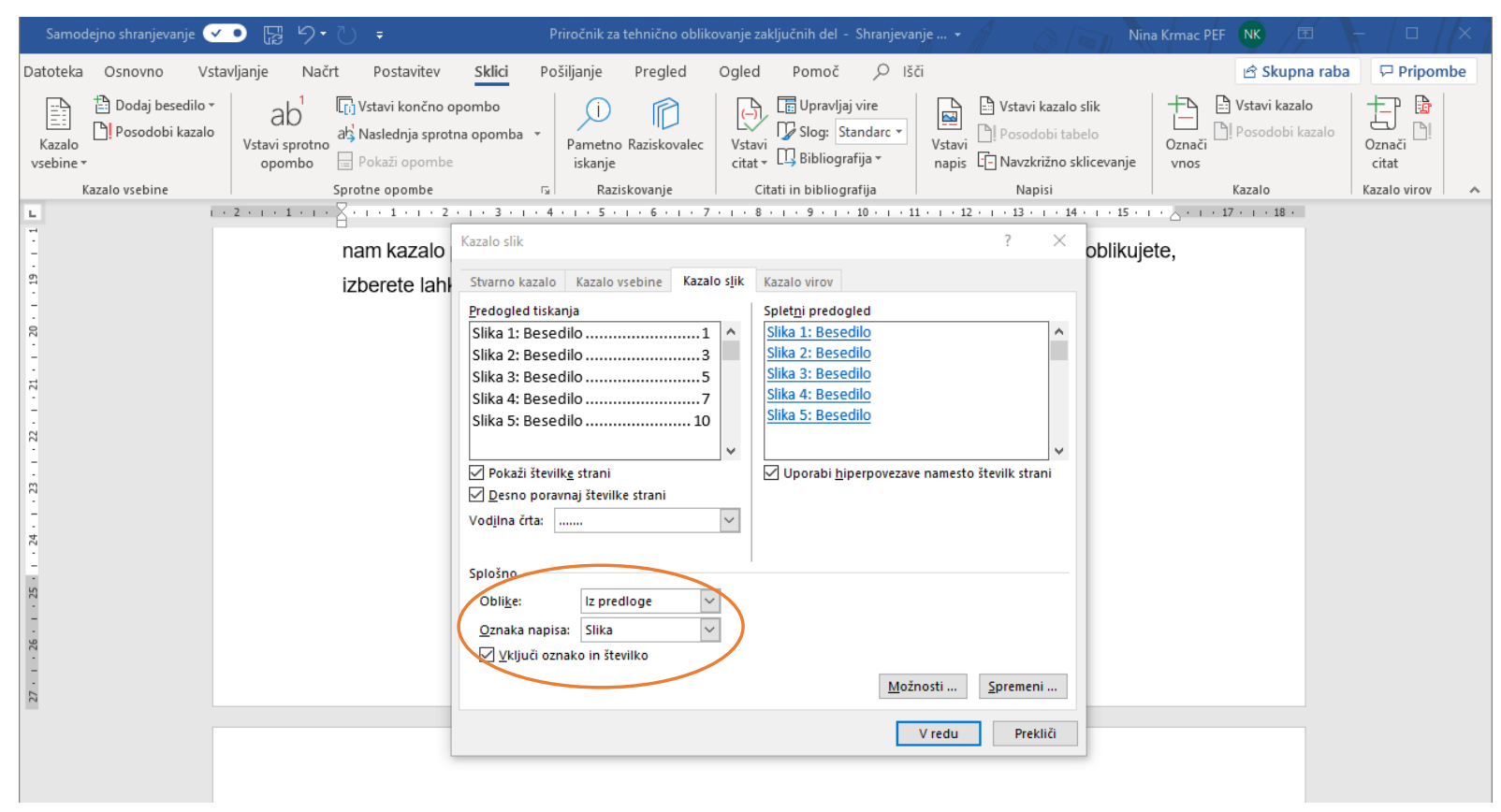

Slika 28: Nastavitev izbire oblikovanja kazala ponazoril

\subsection{Kazalo vsebine}

Kazalo vsebine dodamo na podoben način. Samodejno kazalo se bo oblikovalo, če smo upoštevali navodila poglavja Določanje sloga tekočemu besedilu (glej str. 4). To pomeni, da smo oblikovali sloge, kot jih določajo smernice UP PEF. Torej pri Naslovu 1 nastavimo slog pisave za naslove prve ravni (Arial, 14 pt, krepko, velike tiskane), nadaljujemo z Naslovom 2 (Arial, 12 pt, preko, mala tiskane) itd., kot je zapisano v smernicah UP PEF.

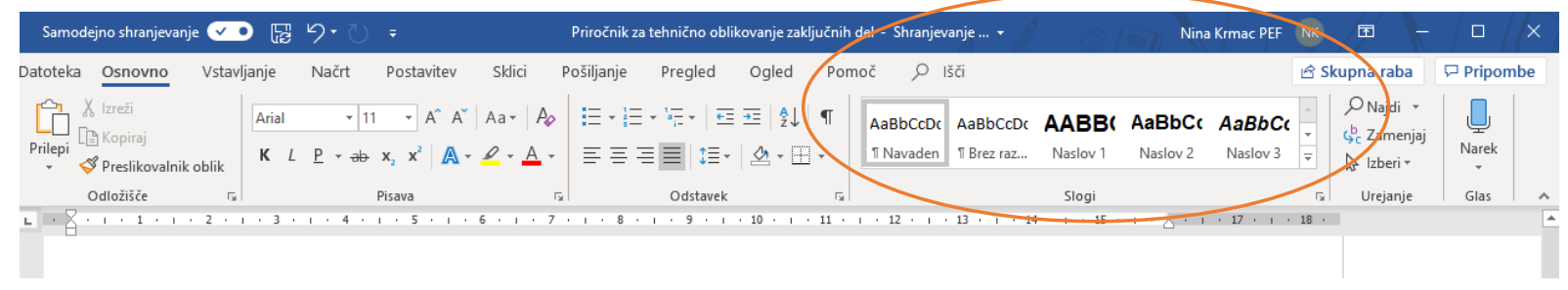

Slika 29: Slogi

Ko je to urejeno, je pomembno, da za naslov vsake ravni označimo, pod kateri naslov spada. Tako bomo lahko dobili pravilno samodejno kazalo, ki ga je mogoče sproti dopolnjevati. 


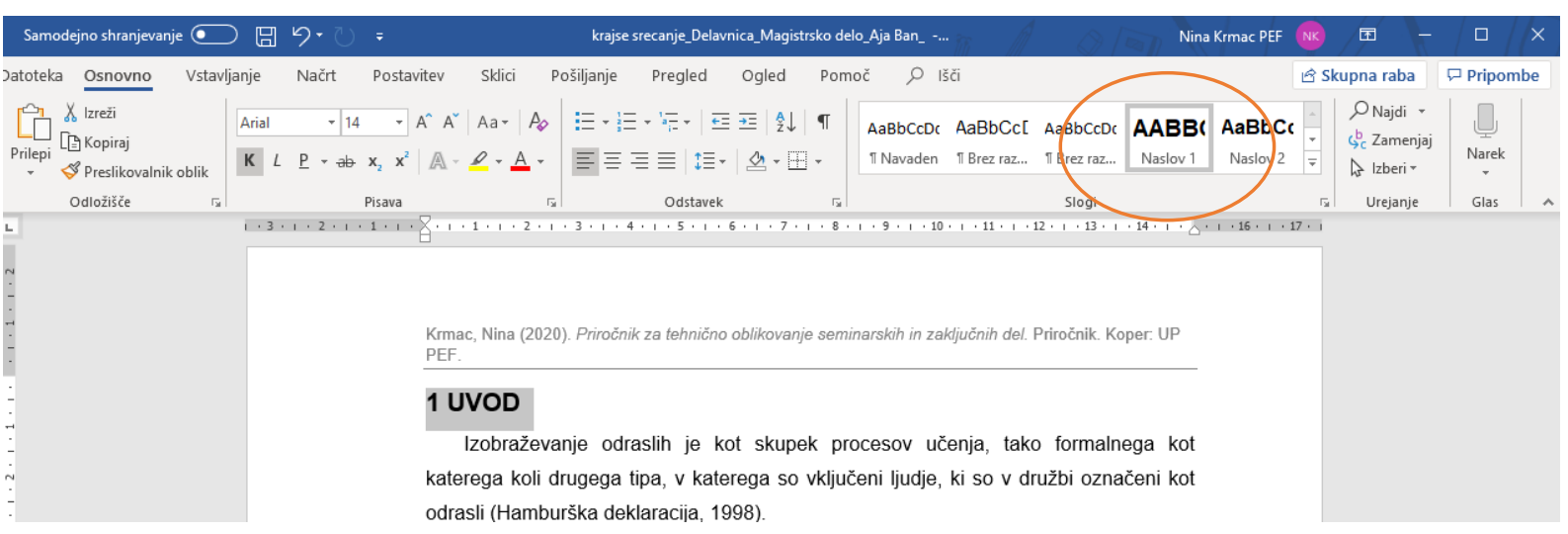

Slika 30: Določitev sloga poglavjem

Označimo torej naslov 1 UVOD in kliknemo na Naslov 1, kot je označeno na zgornji sliki. Čeprav je bil predhodno 1 UVOD napisan v drugem slogu (npr. male tiskane, ležeče), bo s klikom na Naslov 1, 1 UVOD pridobil značilnosti, ki so zahtevane za Naslove prve ravni, kar nam prihrani veliko časa. Zato je dobrodošlo, da sloge nastavimo, preden začnemo pisati dokument. Enako velja za naslove poglavij vseh ostalih ravni. Vse naslove torej označimo, jim določimo slog in v ozadju se bo samodejno oblikovalo kazalo vsebine. Za vstavitev kazala vsebine $v$ dokument ponovno postavimo miško na mesto, kjer želimo vstaviti kazalo vsebine.

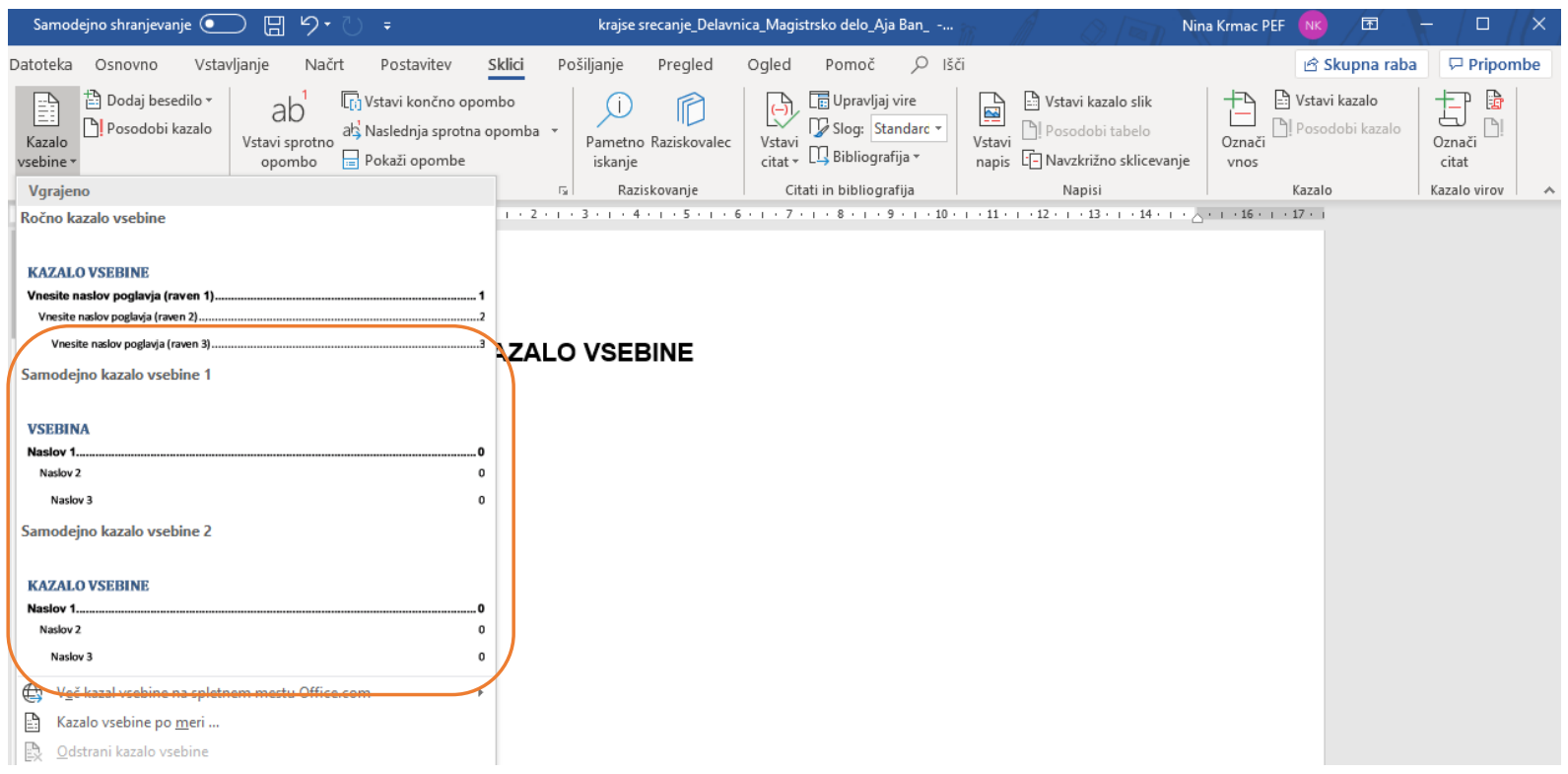

Slika 31: Izbira kazala vsebine

Pod zavihek Sklici kliknemo na Kazalo vsebine in poljubno izberemo Samodejno kazalo vsebine 1 ali 2 . Kliknemo nanj in v dokumentu se nam prikaže kazalo vsebine. 


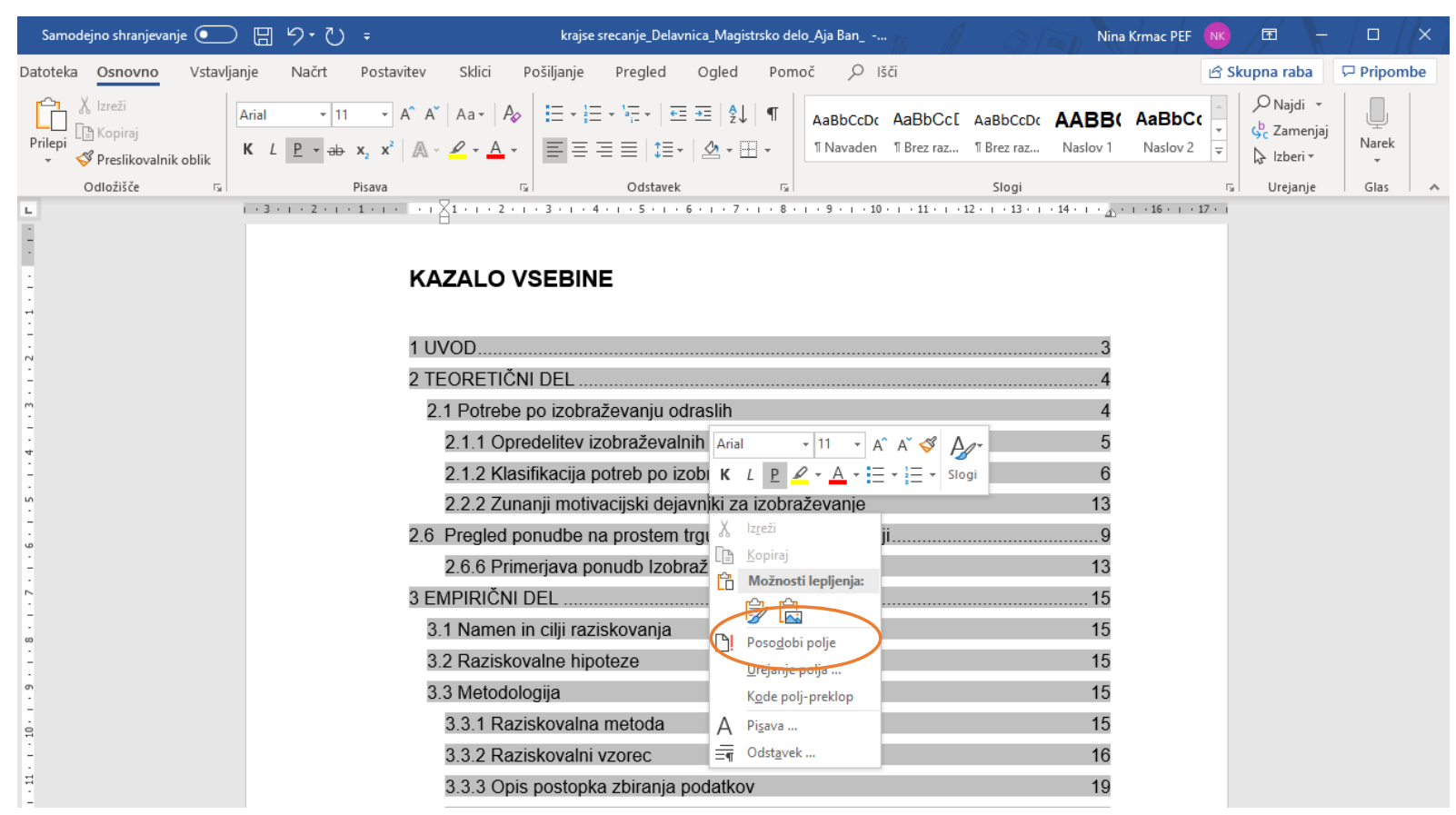

Slika 32: Sprotna posodobitev kazala vsebine

Z desnim klikom na kazalo imamo na voljo ukaz Posodobi polje. Če smo med delom na besedilu dopisali novo besedilo ali dodali nove naslove, je vedno potrebno kazalo posodobiti, da se spremembe prikažejo na njem. Enako velja tudi za Kazala slik, preglednic itd.

$\supseteqq$

Kazala so prvotno nastavljena tako, da samodejno prikazujejo le do tri ravni naslovov poglavij.

Če imamo štiri ravni (smernice UP PEF dopuščajo največ štiri ravni), moramo storiti naslednje: 
Krmac, Nina (2020). Priročnik za tehnično oblikovanje seminarskih in zaključnih del. Priročnik. Koper: UP PEF.

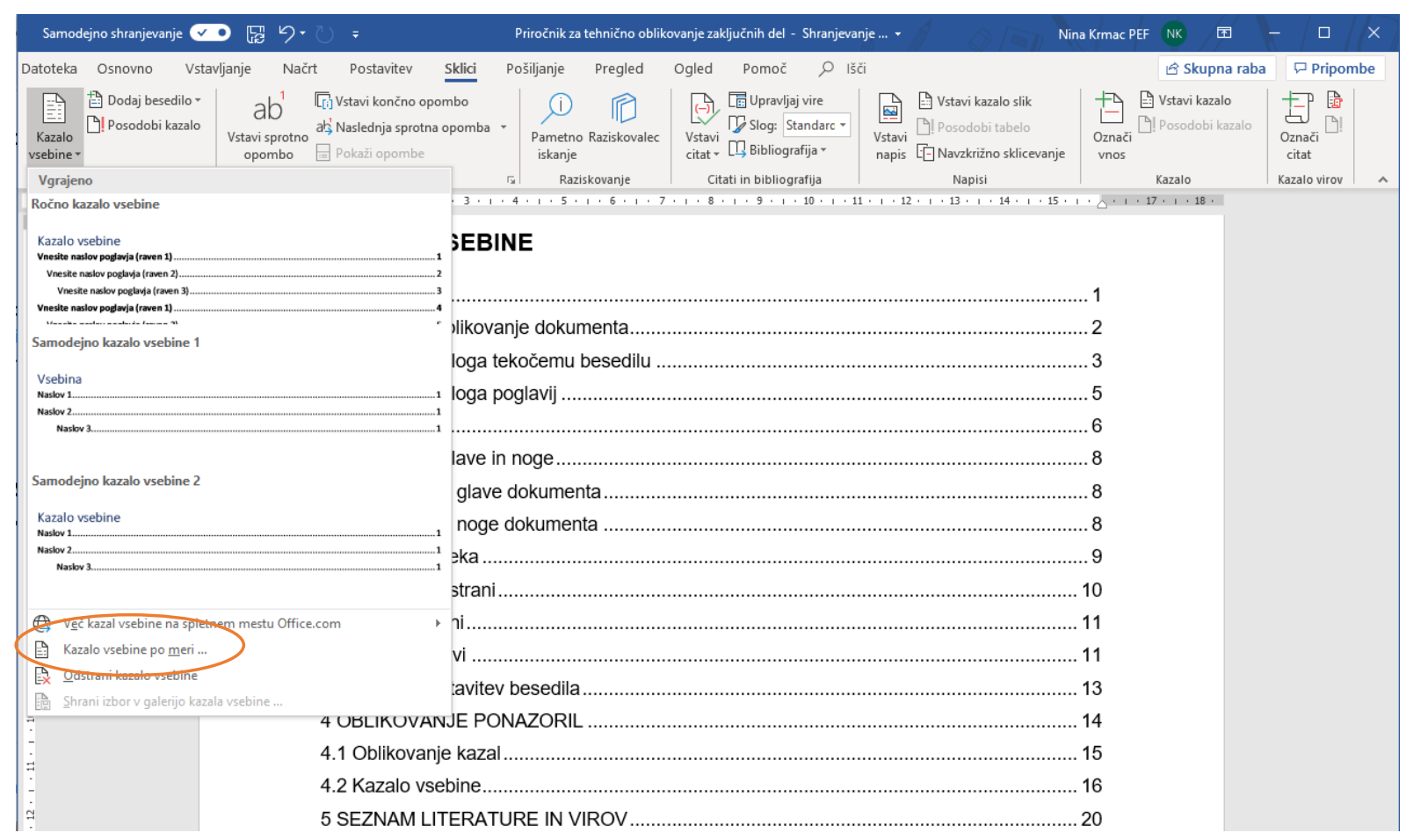

Slika 33: Oblikovanje kazala vsebine po meri

Na enakem mestu, kjer izberemo kazalo vsebine, kliknemo na Kazalo vsebine po meri.

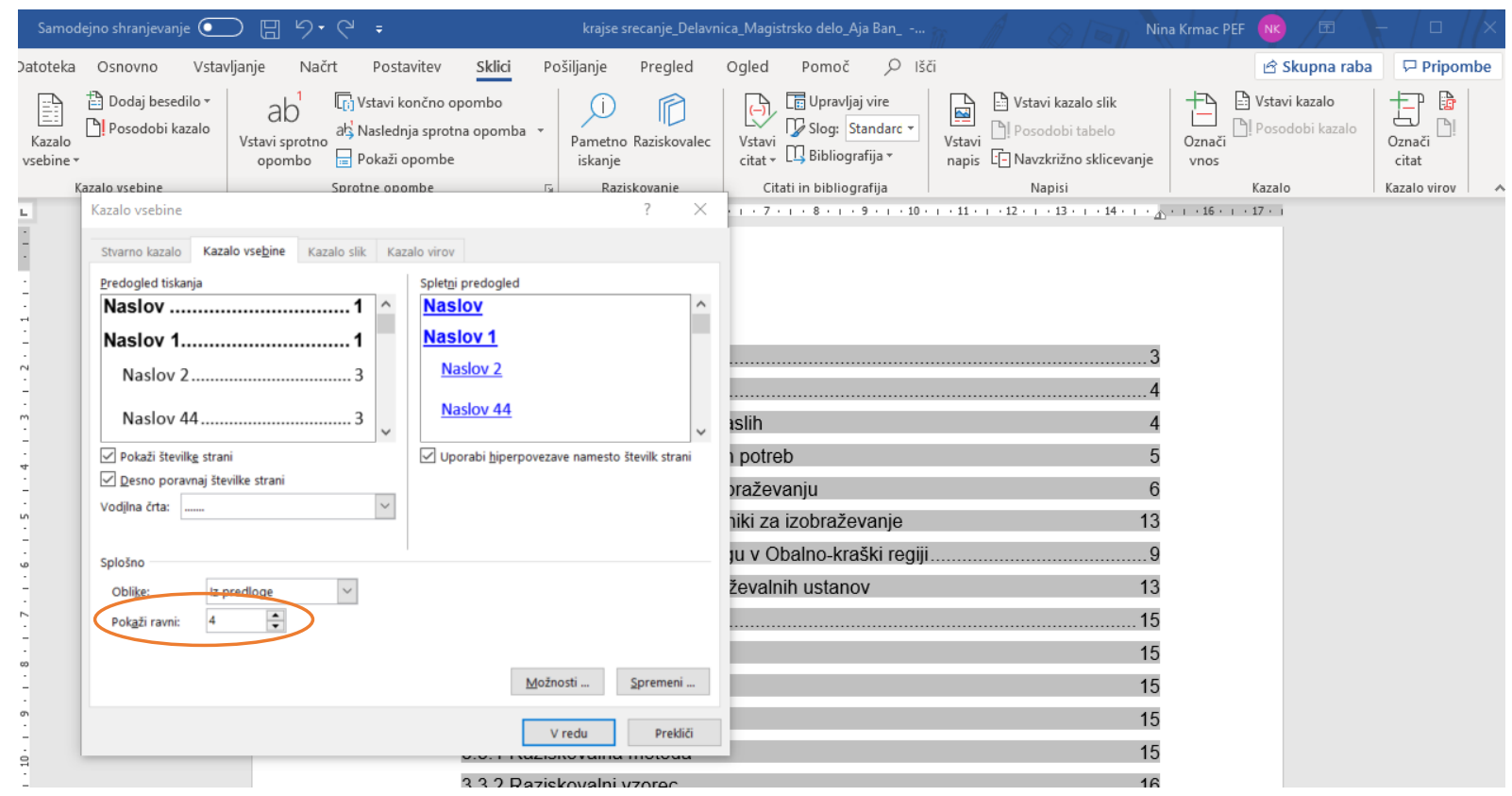

Slika 34: Določitev ravni v kazalu vsebine

V polju Pokaži ravni spremenimo število iz 3 na 4 . Ko kliknemo $\mathbf{V}$ redu, nas bo program vprašal, ali želimo zamenjati kazalo vsebine. Kliknemo $\mathbf{V}$ redu in na kazalu se bodo prikazali tudi naslovi poglavij četrte ravni. Na tem mestu lahko tudi dodatno oblikujemo kazalo vsebine (oblika, vodilna črta itd.). 
Krmac, Nina (2020). Priročnik za tehnično oblikovanje seminarskih in zaključnih del. Priročnik. Koper: UP PEF.

Ne smemo pozabiti, da morajo imeti vsa kazala razmik po odstavku 0 pt in ne 6 pt, kot velja za celoten preostali del besedila. 


\section{SEZNAM LITERATURE IN VIROV}

Pri oblikovanju literature in virov nam je $v$ veliko pomoč preprost ukaz, ki samodejno razvrsti literaturo po abecedi. Tako nam ni potrebno ročno razvrščati uporabljenih virov. Označimo vso literaturo in kliknemo na ukaz $\stackrel{A}{\mathrm{~A}} \downarrow$ v zavihku Osnovno, ki je na sliki označen s krogcem.

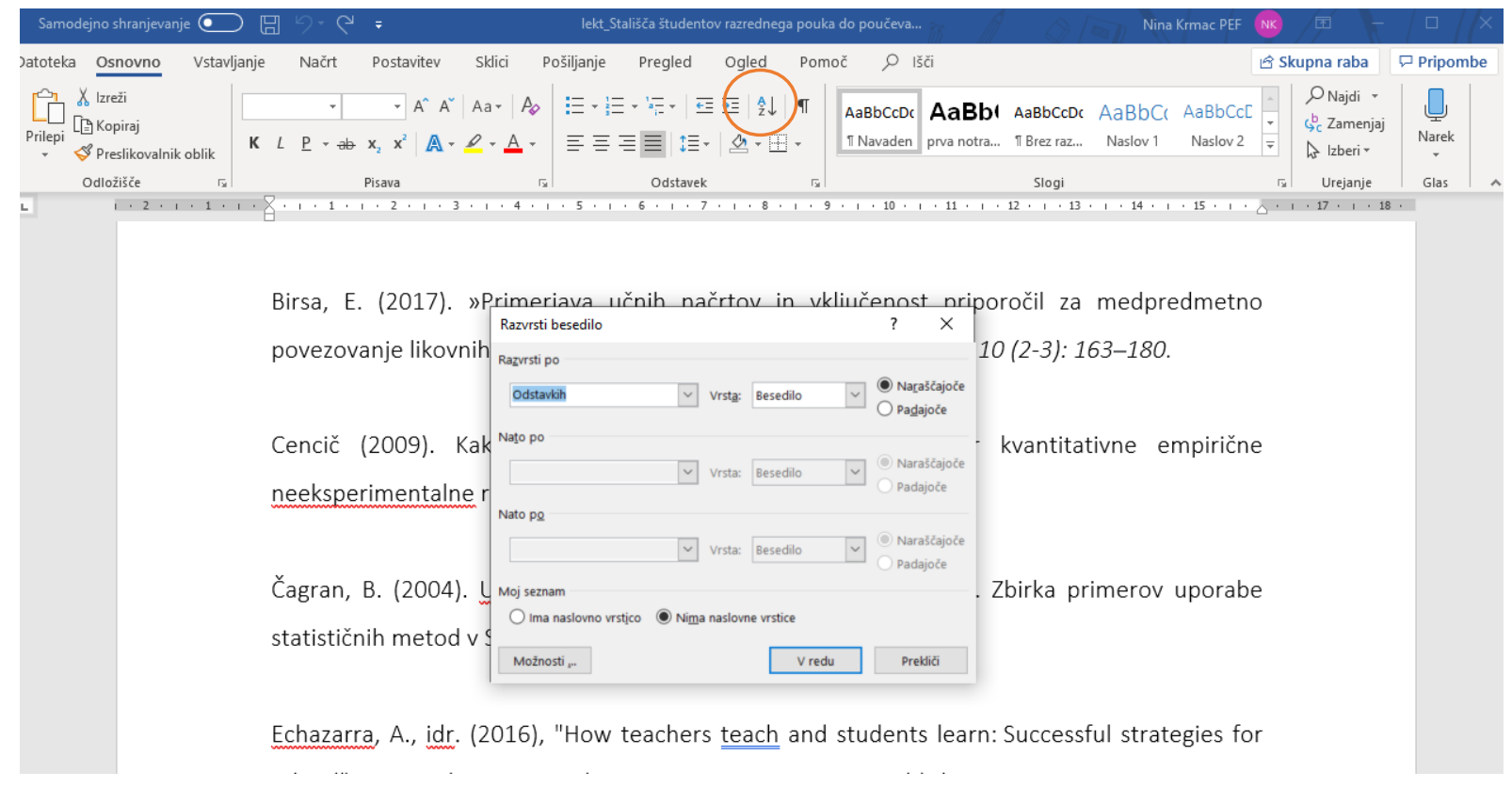

Slika 35: Razvrstitev virov in literature po abecednem vrstnem redu

Če pustimo označeno Naraščajoče, se bo literatura sama razporedila po abecednem vrstnem redu. Najbolje je, da to funkcijo uporabimo na koncu, ko smo že vpisali celotno literaturo.

V smernicah UP PEF glede seznama literature piše, da virov ne številčimo in prednje ne dodajamo označevalcev, temveč jih navajamo kot nove odstavke, pri čemer je zaradi preglednosti prva vrstica vsakega vira pisana brez zamika, naslednje vrstice istega vira pa pišemo z zamikom $0,75 \mathrm{~cm} v$ desno.

To pomeni ravno obratno postavitev $\mathrm{v}$ primerjavi $z$ ostalim besedilom, kjer je prva vrstica pomaknjena $0,75 \mathrm{~cm} v$ desno. To storimo tako, da označimo celotno literaturo, kliknemo na zavihek Osnovno in v razdelku Odstavek kliknemo na (označeno na sliki). Nato v polju Posebni izberemo Viseči in pod Za: napišemo $0,75 \mathrm{~cm}$. 
Krmac, Nina (2020). Priročnik za tehnično oblikovanje seminarskih in zaključnih del. Priročnik. Koper: UP PEF.

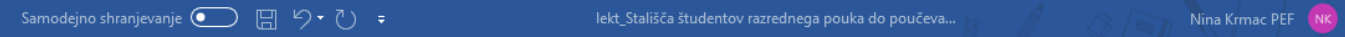

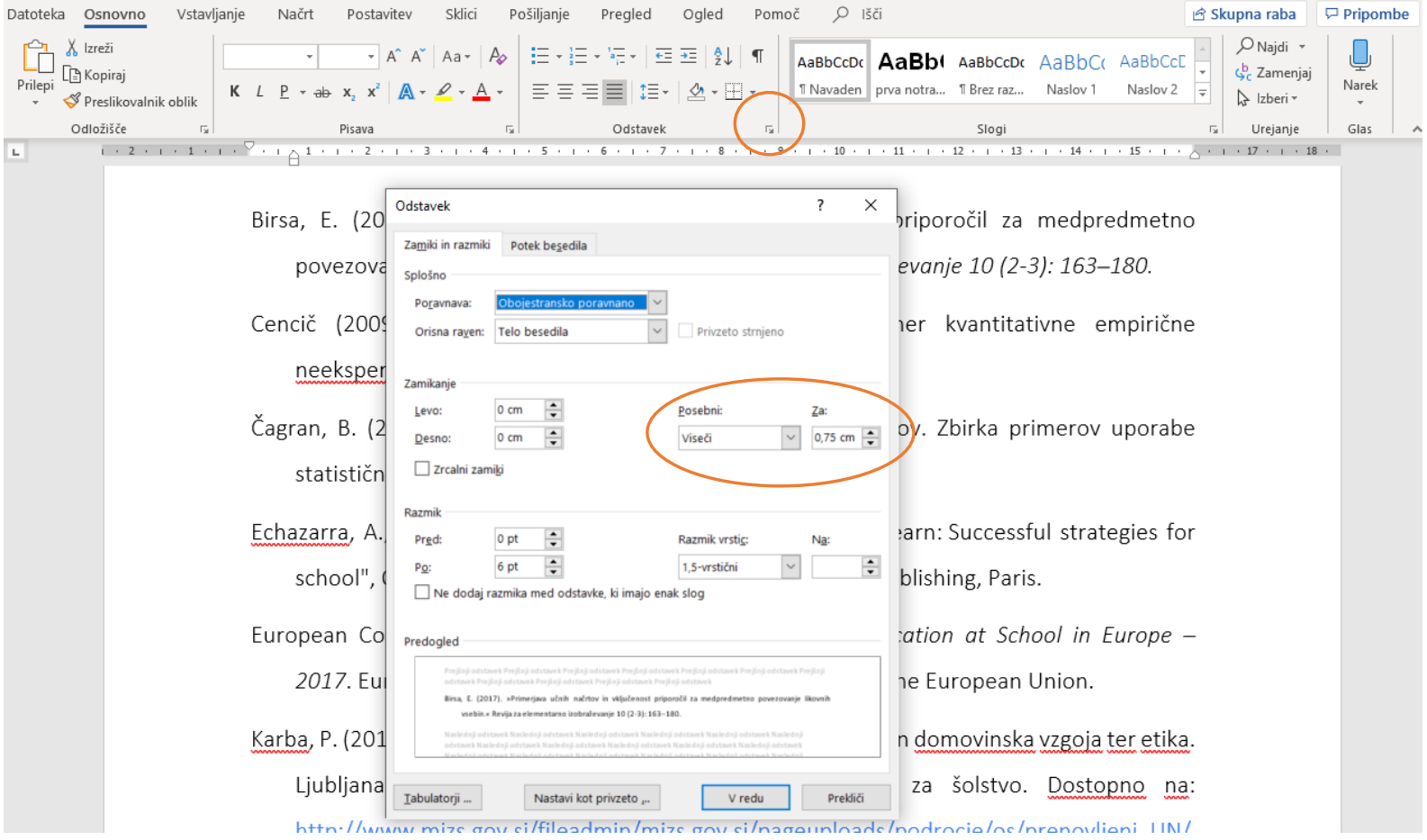

Slika 36: Oblikovanje virov in literature 


\section{UPORABNO}

V nadaljevanju so prikazani še različni ukazi in krajšnice, ki nam pri pisanju in oblikovanju prihranijo kar nekaj časa.

\subsection{Preslikovanje oblik}

S pomočjo funkcije Preslikovanje oblik lahko določeno besedilo, ki smo ga kopirali iz drugega dokumenta in ima drugo pisavo, razmik med vrsticami, torej popolnoma drugačen slog v primerjavi z našimi nastavitvami preslikamo v naš slog dokumenta. Da pridobi tudi ta kopiran del enak slog kot preostali del našega besedila, najprej označimo del našega sloga, kliknemo na Osnovno > Preslikovalnik oblik in nato s prikazanim čopičem označimo tisti del novega besedila, ki mu želimo spremeniti slog pisave.

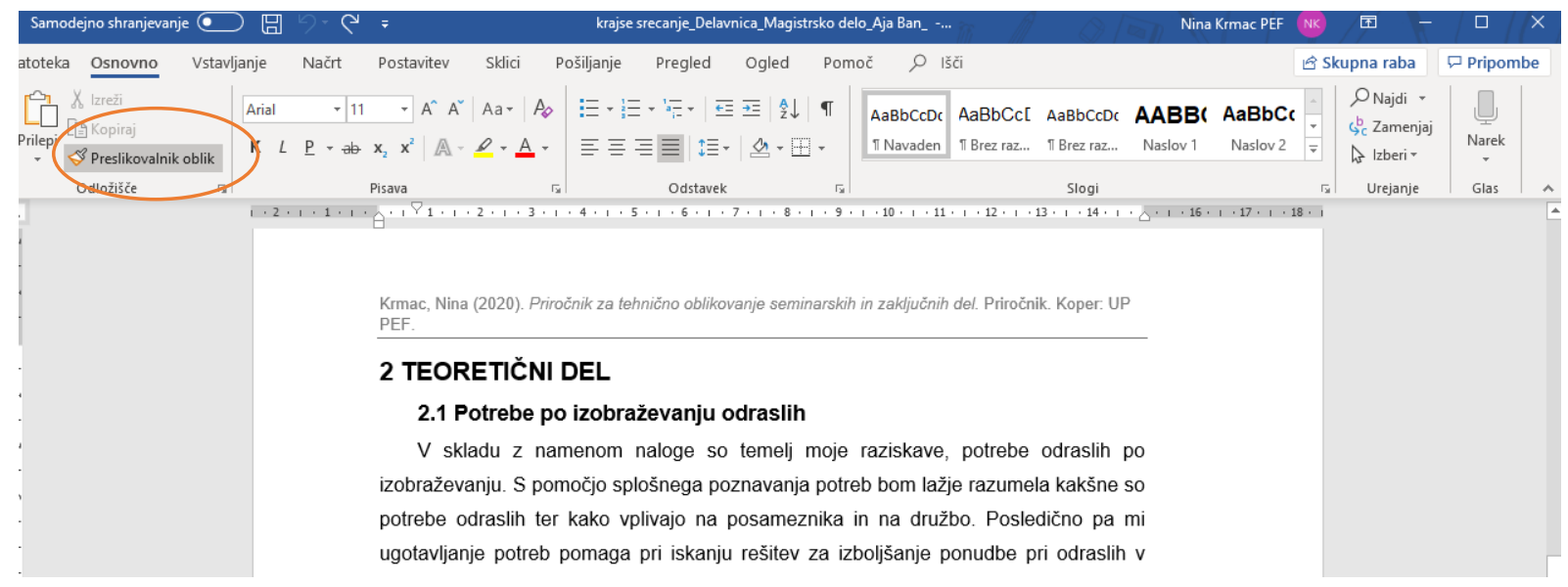

Slika 37: Preslikovanje oblik

\subsection{Odložišče}

Tudi funkcija Odložišče nam lahko prihrani kar nekaj časa. Namenjena je predvsem tistim, ki v dokument kopirajo različne slike ali oblike. Te se hranijo oziroma nalagajo v odložišču in nam jih tako ni potrebno iskati med besedilom, da jih kopiramo in ponovno uporabimo, ampak jih lahko uporabimo iz odložišča. 


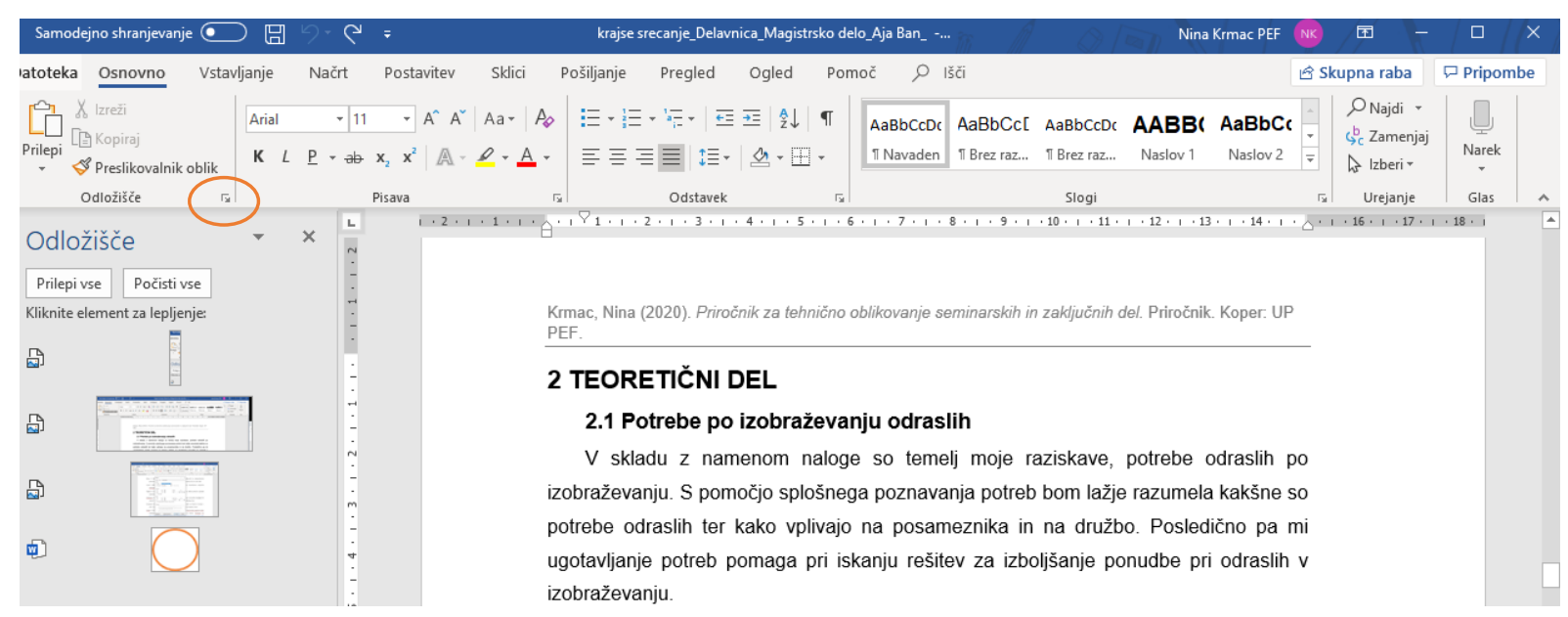

Slika 38: Odložišče

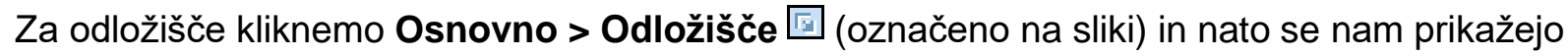
dokumenti, ki so bili prilepljeni in večkrat uporabljeni.

\subsection{Vnos pripombe}

Pri pisanju obsežnejšega besedila je zelo uporabno, če si pri besedilu pišemo pripombe, da česa ne pozabimo ali si pripišemo, kaj moramo še dopisati. V pripombo si lahko tudi vnesemo povezavo do literature, ki bi jo bilo smiselno še vključiti v določeno poglavje.

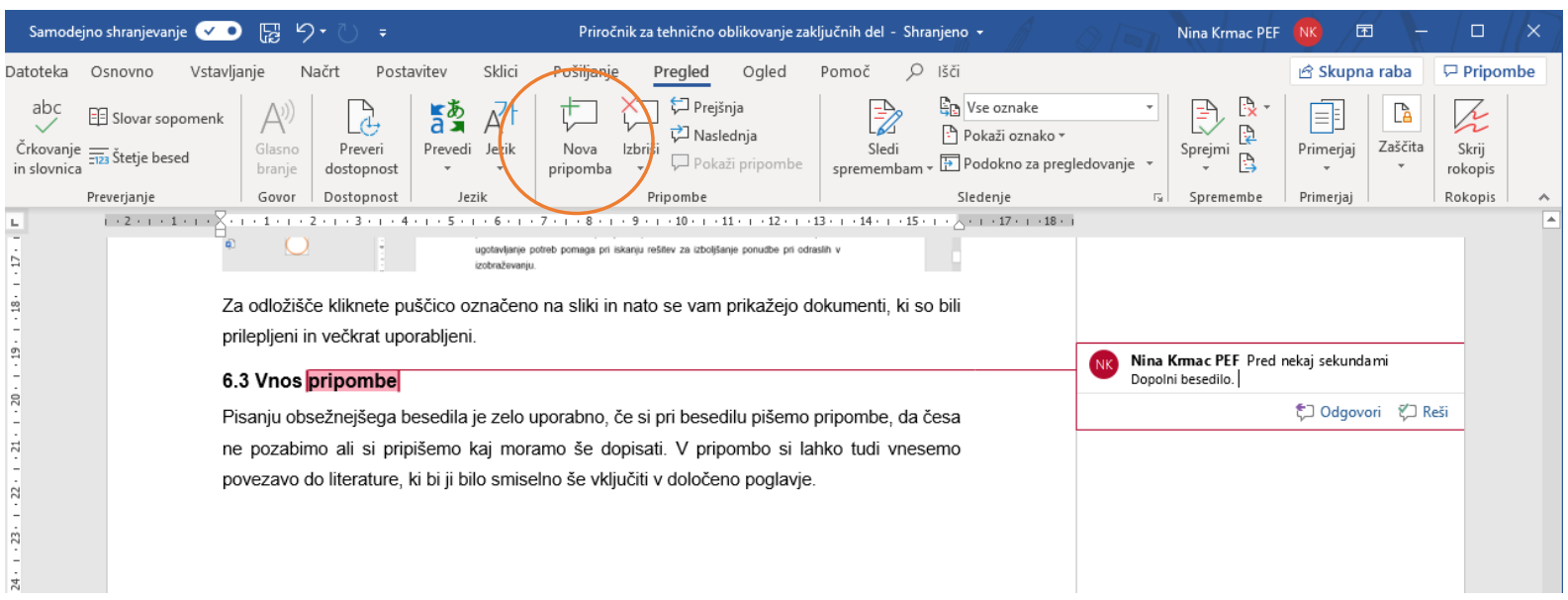

Slika 39: Vnos pripombe v besedilo

Funkcija Nova pripomba se nahaja pod zavihkom Pregled. Nato označimo besedilo, kjer želimo nekaj pripisati in kliknemo Nova pripomba (označeno na sliki). 


\subsection{Sprotna opomba}

Po smernicah UP PEF so sprotne opombe na isti strani kot besedilo ( $v$ nogi besedila), na katerega se nanašajo. Oštevilčene so z arabskimi številkami.

Sprotno opombo vnesemo tako, da označimo besedo, ki jo želimo podrobneje opisati. Kliknemo na zavihek Sklici in nato Vstavi sprotno opombo. Tudi sprotne opombe se samodejno posodobljajo. To pomeni, da če bomo vmes dodali še kakšno opombo, se bodo številke opomb same spremenile.

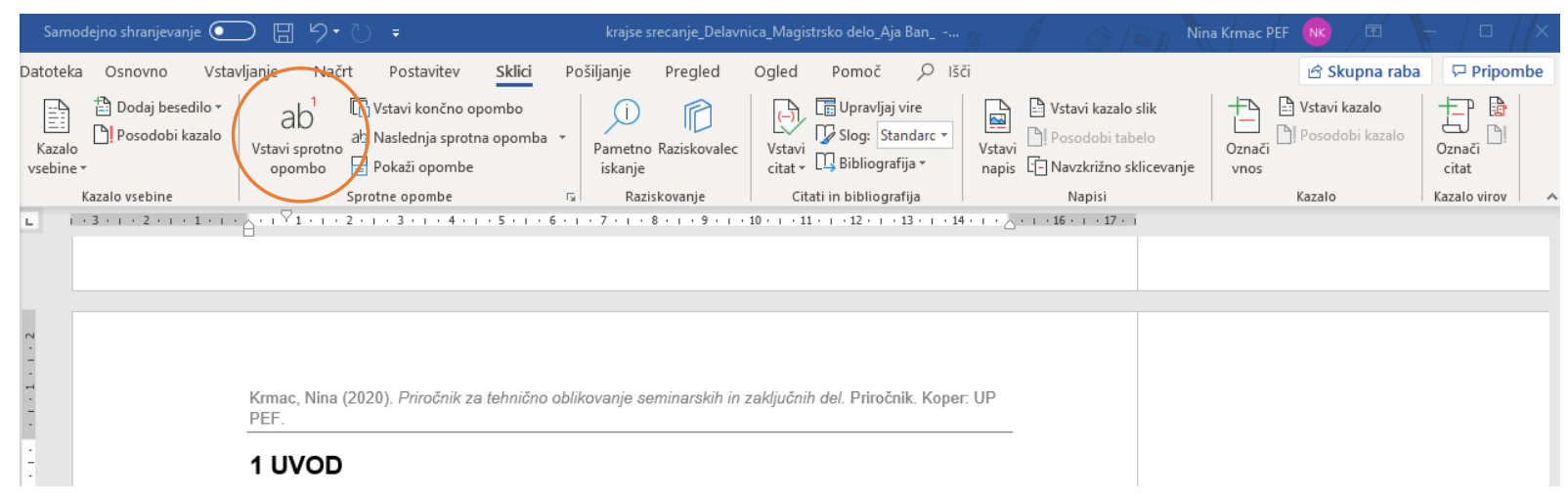

Slika 40: Vstavljanje sprotne opombe

\subsection{Sledi spremembam}

Če bomo zaključno ali projektno delo delali v skupini z več osebami, je zelo dobrodošla uporaba funkcije Sledi spremembam. Ta omogoča, da sledimo novim spremembam, ki so nastale na dokumentu. Če se s spremembo strinjamo, jo lahko sprejmemo, če se z njo ne strinjamo, pa jo lahko tudi zbrišemo.

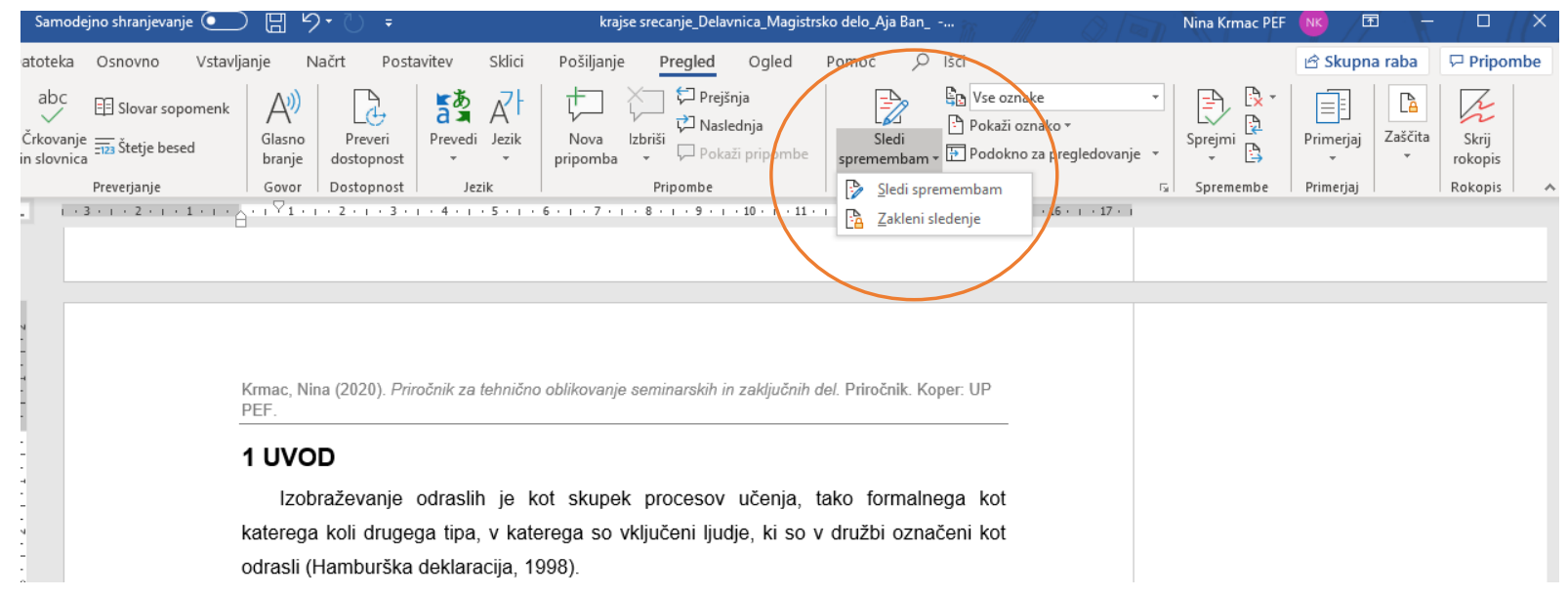

Slika 41: Vklop/lzklop sledenja spremembam 
Funkcija Sledi spremembam se nahaja pod zavihkom Pregled > Sledi spremembam. Če spremembam ne želimo več slediti, zgolj ponovno kliknemo na Sledi spremembam.

Če želimo sprejeti vse spremembe, kliknemo na Sprejmi in izberemo opcijo, ki nam najbolj ustreza, kot je prikazano na spodnji sliki.

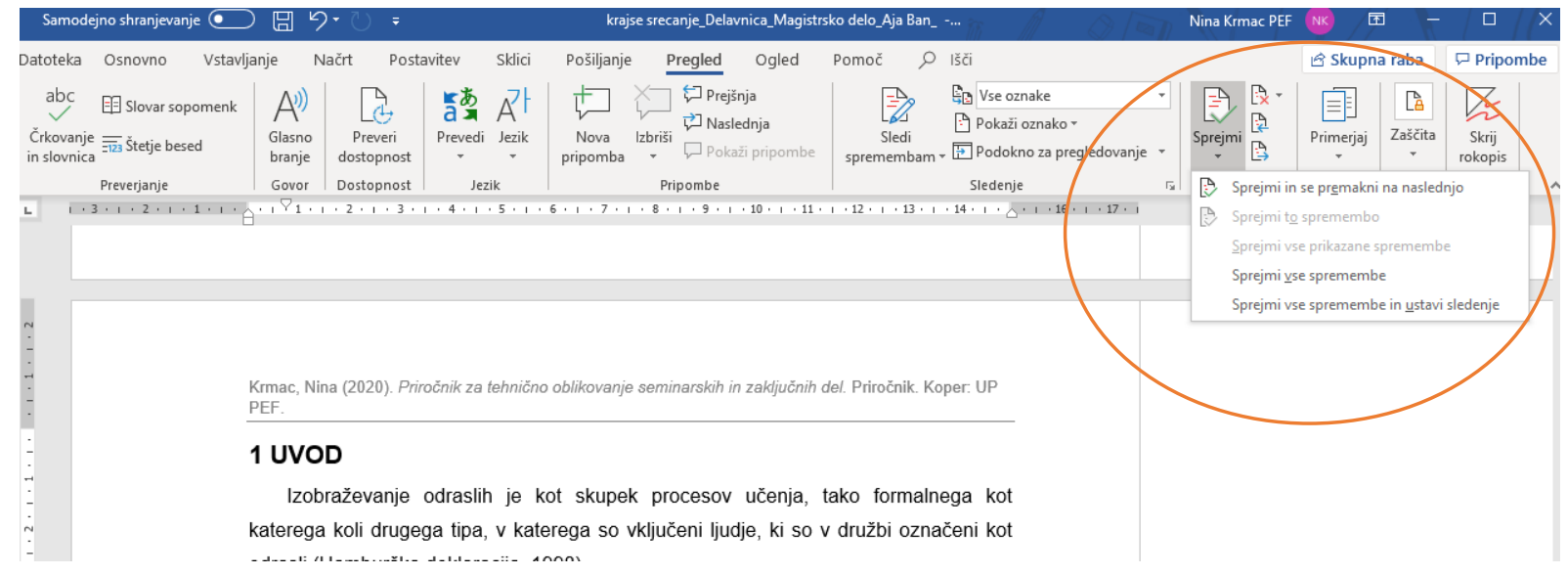

Slika 42: Urejanje sledenja spremembam

\subsection{Gumb Pokaži/skrij đ}

Pri delu nam je lahko večkrat $v$ pomoč gumb Pokaži/skrij (đ). S klikom nanj se nam prikažejo vsi skriti znaki in ukazi, ki smo jih nastavili v dokumentu. Posebej prav pride, ko določenega dela besedila ne moremo urediti, kot želimo. $S$ klikom na ta gumb bomo lahko videli, kaj je dejansko v ozadju nastavljeno in zakaj nismo mogli spremeniti določenega dela besedila ali izvesti določene funkcije. S pomočjo tega gumba lahko tudi vidimo, kje $v$ besedilu se nahajajo prelomi strani, odsekov itd.

Gumb se nahaja v zavihku Osnovno, kot je razvidno iz spodnje slike.

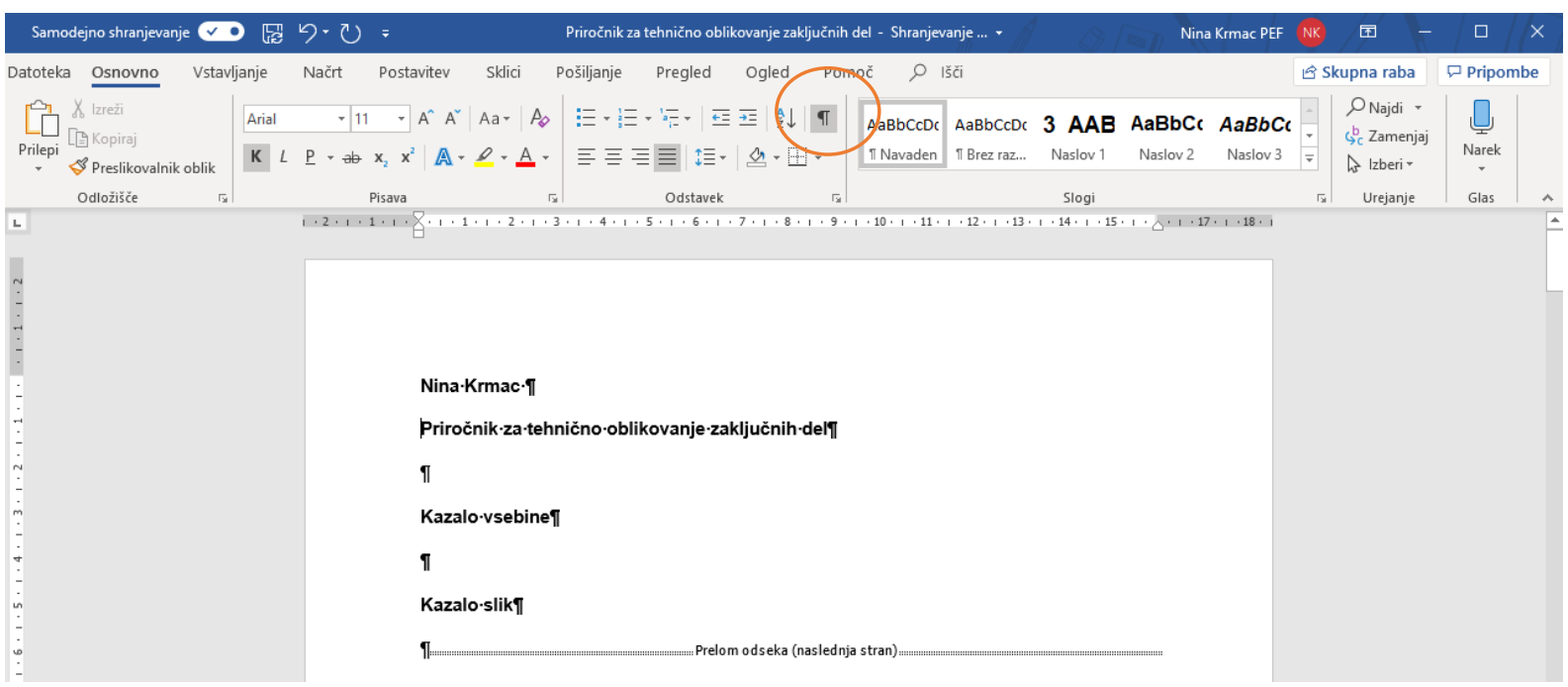

Slika 43: Gumb Pokaži/skrij 


\subsection{Odstranjevanje skritih podatkov in osebnih informacij}

Vsak dokument, ki ga oblikujemo, shranjuje podatke o našem delu in naših osebnih informacijah. Ti podatki se nahajajo pod zavihkom Datoteka > Informacije, kot je prikazano na spodnji sliki.

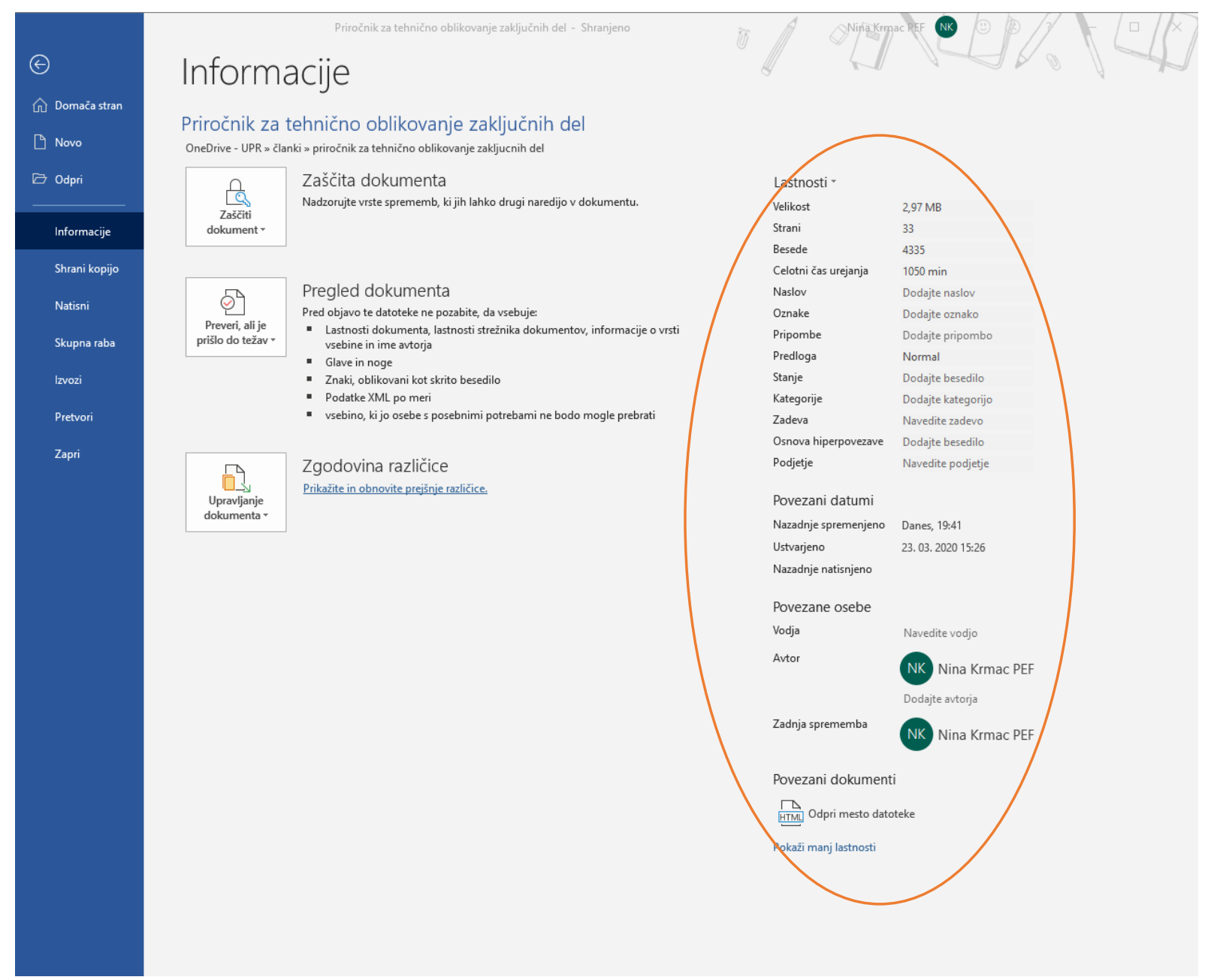

Slika 44: Informacije o dokumentu

To pomeni, da vsak, ki mu posredujemo naš dokument (kolega, profesor, prijatelj ...), lahko prebere, kdo je avtor besedila, če je morda še kdo dodatno urejal besedilo, koliko časa smo urejali besedilo itd. V kolikor želimo skriti ali izbrisati podatke v dokumentu, ki kažejo na naše avtorstvo in potek dela, je to mogoče opraviti s pomočjo naslednjih korakov. 


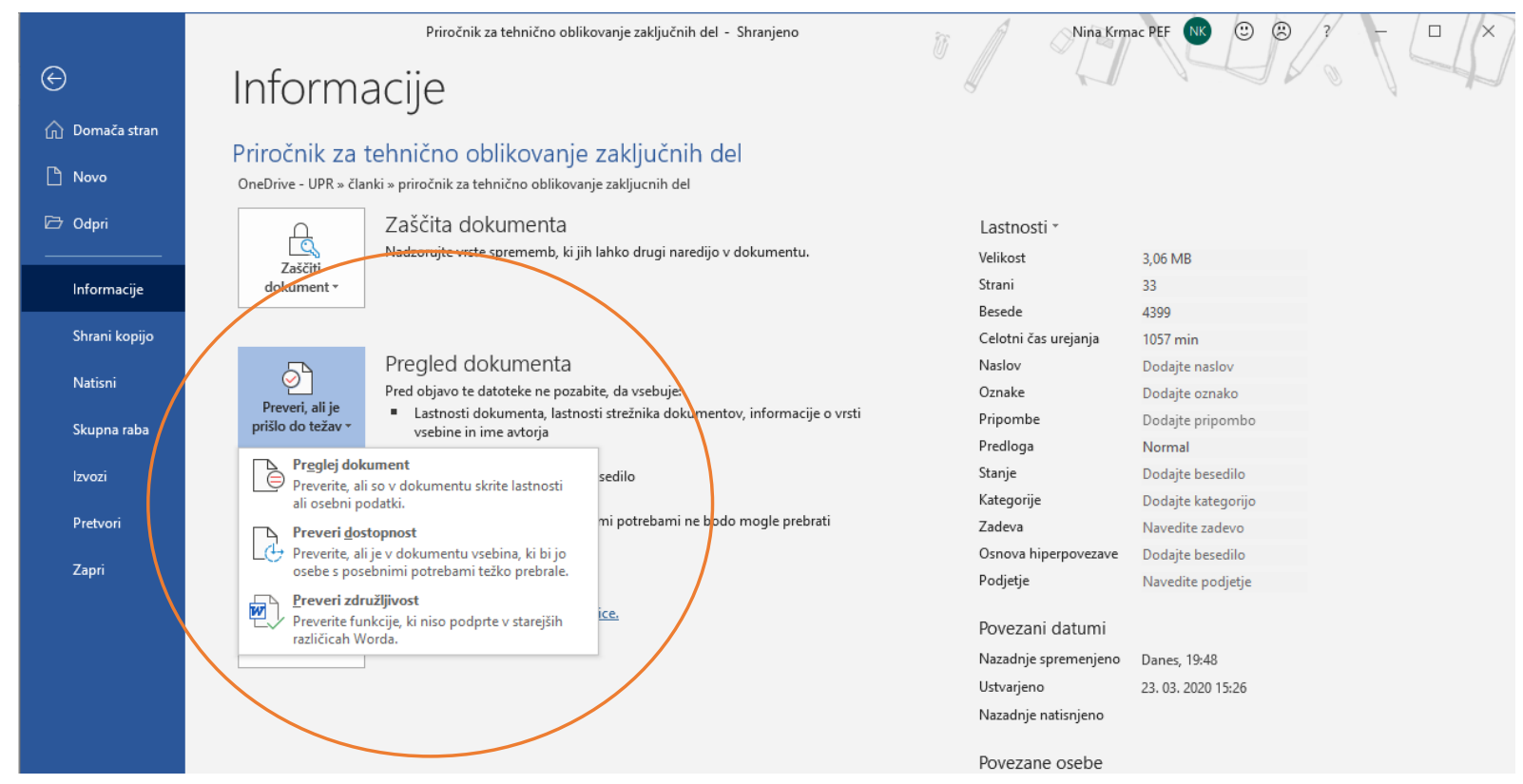

Slika 45: Pregled informacij v dokumentu

Najprej kliknemo na gumb Pregled dokumenta in kliknemo Preglej dokument. Prikazalo se nam bo naslednje pogovorno okno, v katerem kliknemo Preglej.

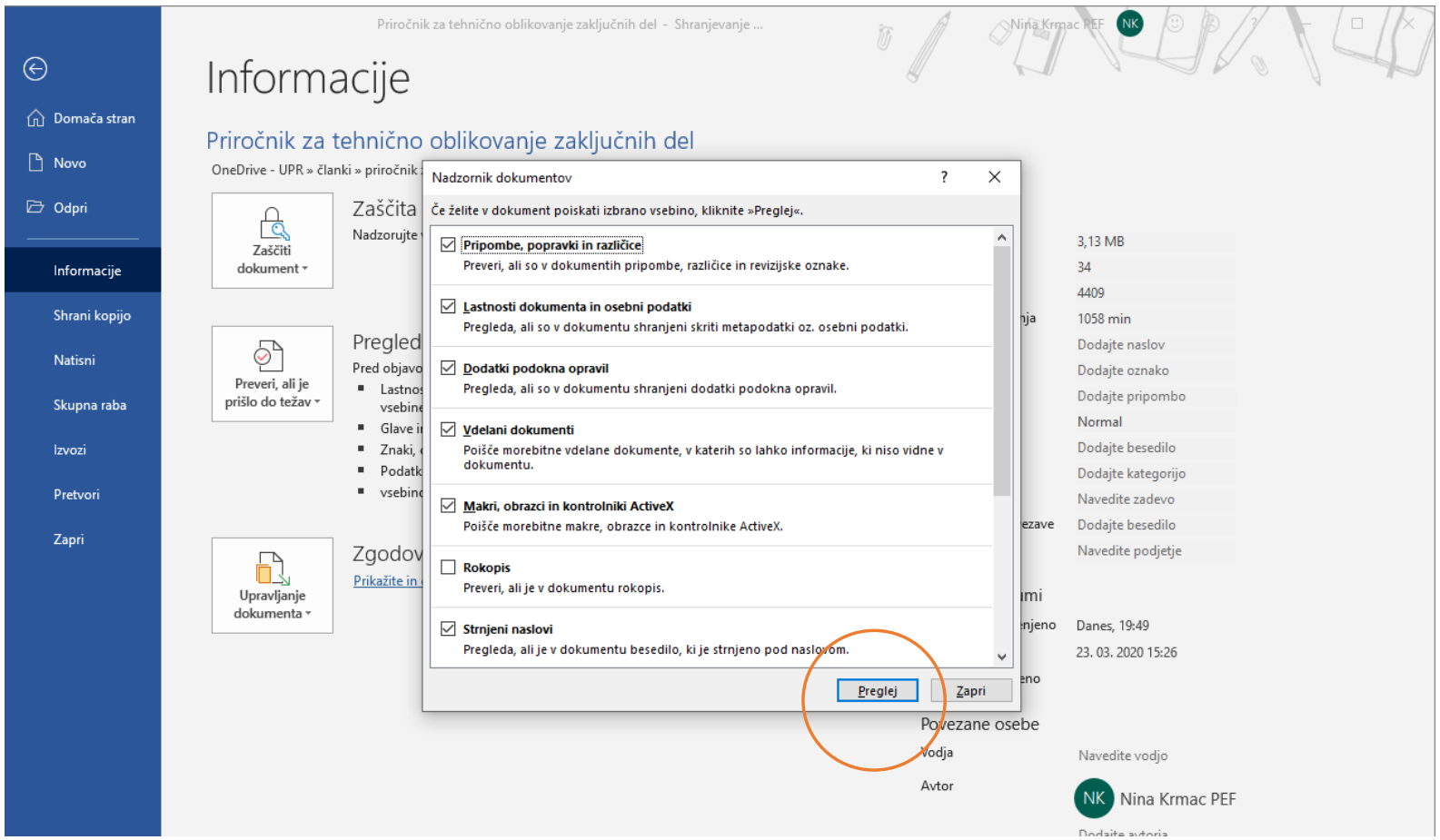

Slika 46: Izpis informacij dokumenta

Prikažejo se lastnosti dokumenta, ki so bile najdene. 


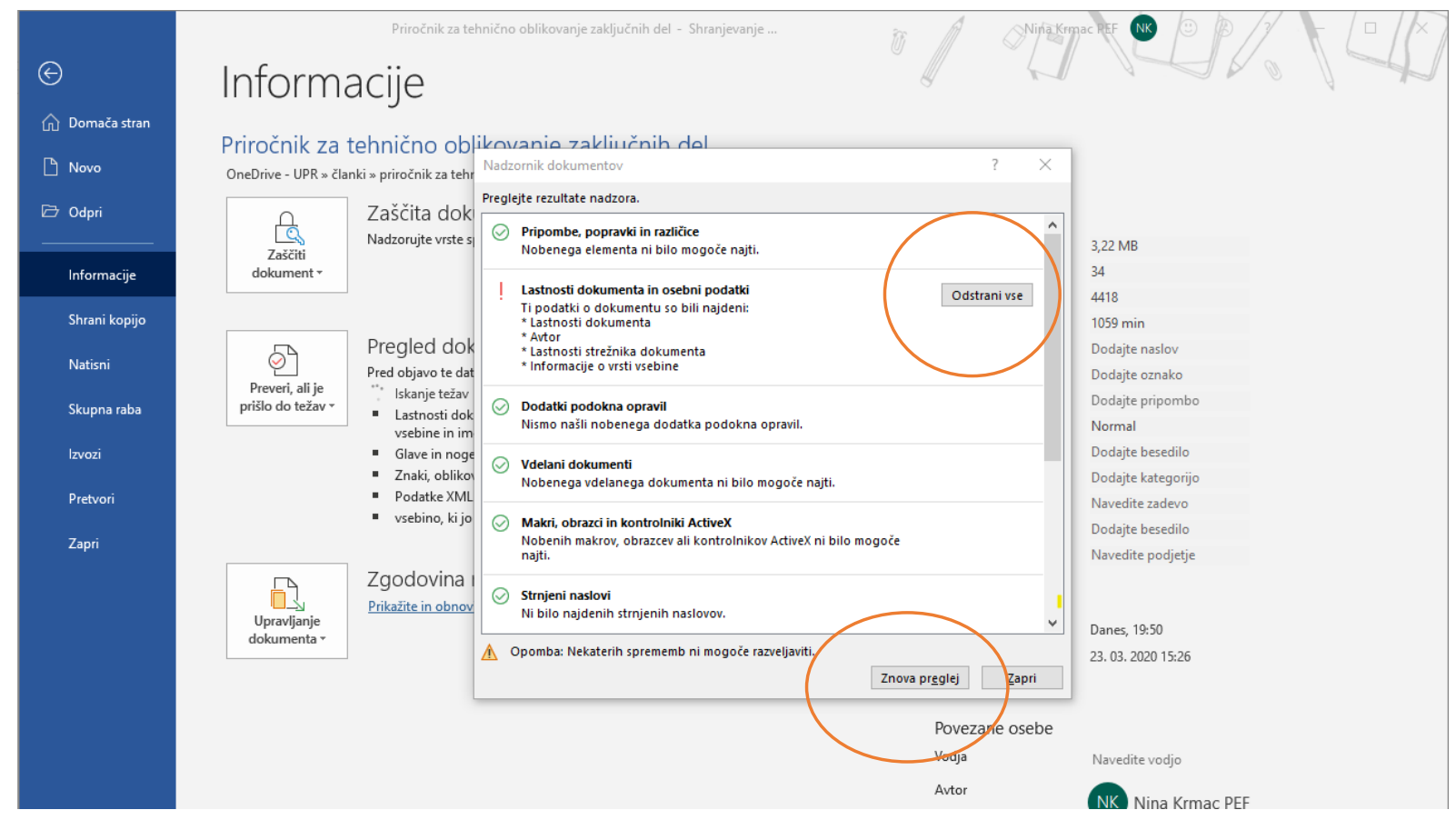

Slika 47: Izbris informacij o dokumentu

\section{Nato kliknemo Odstrani vse, zatem pa Znova preglej.}

Pod Informacije so bodo prikazali naslednji podatki:

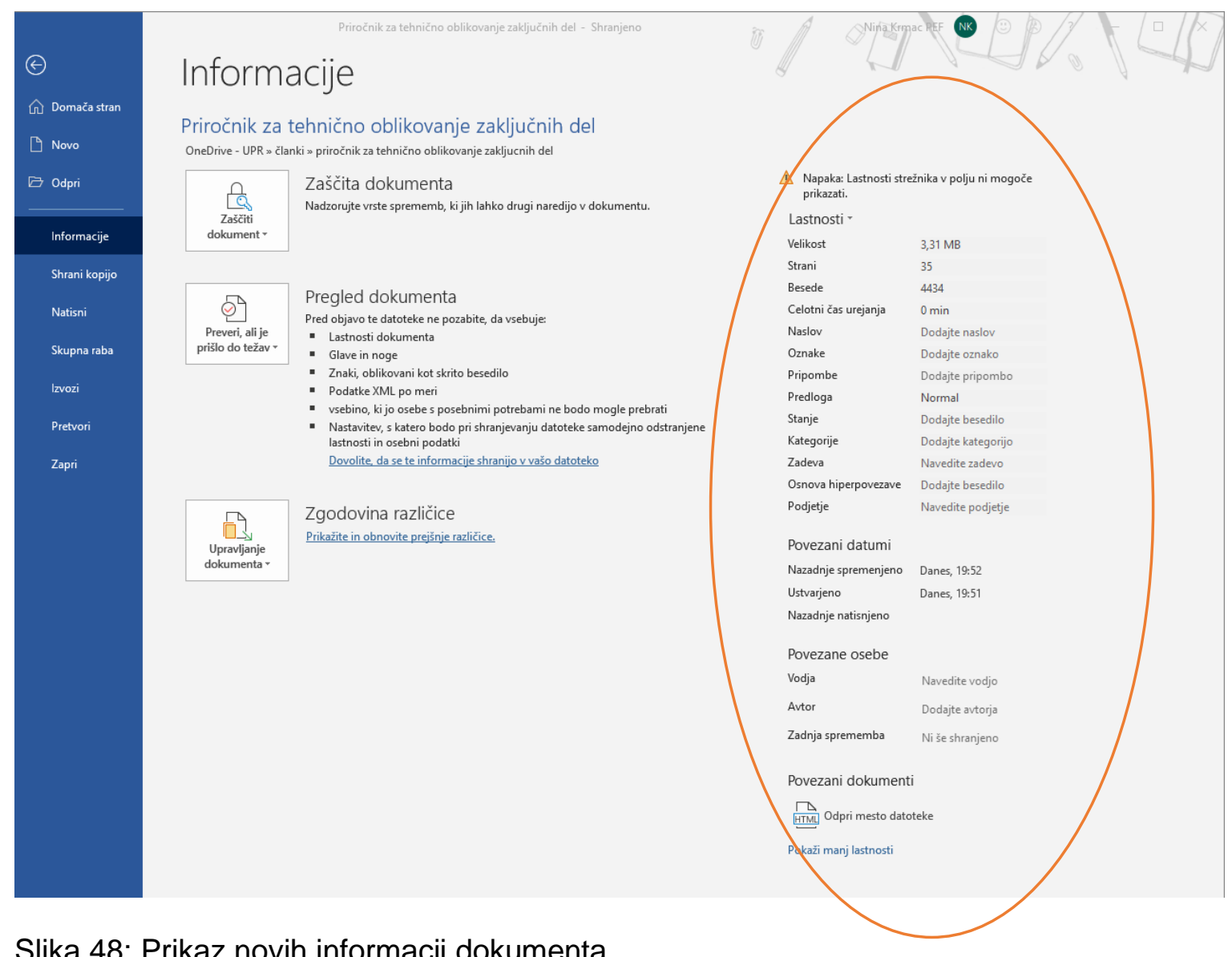

Slika 48: Prikaz novih informacij dokumenta 


\section{DOBRODOŠLE FUNKCIJE NA TIPKOVNICI}

V tem poglavju so prikazane še krajšnice na tipkovnici, ki nam lahko prihranijo kar nekaj časa. Izpostavljene so predvsem tiste, ki se ne uporabljajo pogosto, a so marsikdaj dobrodošle.

\subsection{Uveljavitev prejšnjega dejanja}

Za uveljavitev prejšnjega dejanja imamo možnost uporabe dveh ukazov, tj. tipke F4 ali Ctrl+Y. S pomočjo obeh lahko ponovimo zadnje opravljeno dejanje. Marsikatero urejanje tako lahko bistveno hitreje opravimo. Ukaz je koristen predvsem pri oblikovanju preglednic in zamikov $v$ besedilu.

\subsection{Razdelitev okna dokumenta}

Ta ukaz je koristen predvsem pri urejanju obširnih dokumentov. Pritisnemo na $\mathbf{C t r l + A l t + S}$ in dokument se bo na mestu, kjer imamo postavljeno miško, razdelil na dve okni. To pomeni, da lahko ločeno v zgornjem delu besedila brskamo in iščemo podatke, medtem ko spodnji del besedila ostane točno na tistem mestu, kjer želimo nadaljevati s pisanjem. Za izključitev tega ukaza zgolj ponovno pritisnemo Ctrl+Alt+S.

\subsection{Ostale bližnjice na tipkovnici}

Preglednica 1: Bližnjice na tipkovnici (povzeto po Bližnjice na tipkovnici v Wordu, 2020)

\begin{tabular}{|l|l|}
\hline Dejanje & Tipke \\
\hline Odpiranje dokumenta. & Ctrl+O \\
\hline Ustvarjanje novega dokumenta & Ctrl+N \\
\hline Shraniti dokument. & $\mathrm{CTRL}+\mathrm{S}$ \\
\hline Zapreti dokument. & $\mathrm{CTRL}+\mathrm{W}$ \\
\hline Uporaba krepkega oblikovanja v besedilu. & $\mathrm{Ctrl}+\mathrm{B}$ \\
\hline Uporaba ležečega oblikovanja v besedilu. & $\mathrm{Ctrl}+\mathrm{I}$ \\
\hline $\begin{array}{l}\text { Uporaba podčrtanega oblikovanja } \\
\text { besedilu. }\end{array}$ & $\mathrm{Ctrl}+\mathrm{U}$ \\
\hline Poravnava besedila na levo. & $\mathrm{Ctrl}+\mathrm{L}$ \\
\hline Poravnava besedila na desno. & $\mathrm{Ctrl}+\mathrm{R}$ \\
\hline
\end{tabular}




\begin{tabular}{|c|c|}
\hline Premik kazalca na konec dokumenta. & Ctrl + End \\
\hline Premik kazalca na začetek dokumenta. & Ctrl + Home \\
\hline $\begin{array}{l}\text { Izbor od trenutnega položaja do začetka } \\
\text { trenutne vrstice. }\end{array}$ & Shift+Home \\
\hline $\begin{array}{l}\text { Izbor iz trenutnega položaja na konec } \\
\text { trenutne vrstice. }\end{array}$ & Shift + End \\
\hline $\begin{array}{l}\text { Izbor od trenutnega položaja do začetka } \\
\text { trenutnega odstavka. }\end{array}$ & CTRL + SHIFT + puščična tipka gor \\
\hline $\begin{array}{l}\text { Izbor iz trenutnega položaja do konca } \\
\text { trenutnega odstavka. }\end{array}$ & CTRL + SHIFT + puščična tipka dol \\
\hline $\begin{array}{l}\text { Izbor med trenutnim položajem na vrhu } \\
\text { zaslona. }\end{array}$ & SHIFT + PAGE up \\
\hline Izbor od trenutnega položaja do dna zaslona. & SHIFT + PAGE dol \\
\hline $\begin{array}{l}\text { Izbor od trenutnega mesta do začetka } \\
\text { dokumenta. }\end{array}$ & Ctrl+Shift+Home \\
\hline $\begin{array}{l}\text { Izbor od trenutnega položaja do konca } \\
\text { dokumenta. }\end{array}$ & Ctrl+Shift+End \\
\hline Brisanje ene besede $v$ levo. & Ctrl+Backspace \\
\hline Brisanje ene besede $v$ desno. & Ctrl+Delete \\
\hline Uporaba razmika 1,5 med vrsticami. & $\mathrm{Ctrl}+5$ \\
\hline Uporaba enojnega razmika med vrsticami. & $\mathrm{Ctrl}+1$ \\
\hline Vstavljanje preloma strani. & Ctrl + Enter \\
\hline Vstavljanje pripombe. & Ctrl+Alt+M \\
\hline Vklop ali izklop sledenja sprememb. & Ctrl+Shift+E \\
\hline Vstavljanje sprotne opombe. & $\mathrm{Ctrl}+\mathrm{Alt}+\mathrm{F}$ \\
\hline
\end{tabular}




\section{ZAKLJUČEK}

S priročnikom smo zaobjeli bistvene nastavitve, ki se zahtevajo v okviru smernic UP PEF in pri oblikovanju vsakega dokumenta. Pri oblikovanju dokumenta je lahko v dodatno pomoč tudi naslednja povezava: https://bit.ly/2Yv1VT8.

Če ste pri uporabi priročnika pogrešali določene obrazložitve ali ukaze, ki bi vam pri urejanju dokumenta bile v pomoč, le-te sporočite na nina.krmac@pef.upr.si in bodo lahko v novi izdaji priročnika dodane. 


\section{LITERATURA}

Bližnjice na tipkovnici v Wordu. (2020). Pridobljeno 26. 4. 2020, https://bit.ly/2y8JZD5.

Smernice za izdelavo zaključnih del UP PEF. (2015). Pridobljeno 1. 3. 2020, https://www.pef.upr.si/studenti/zakljucek studija/. 